\title{
Comparative Efficacy of Commonly Available Human Bone Graft Substitutes as Tested for Posterolateral Fusion in an Athymic Rat Model
}

\author{
NEIL BHAMB, MD,${ }^{1}$ LINDA E. A. KANIM, MA, ${ }^{2}$ SUSAN DRAPEAU, PHD,${ }^{3}$ SUNEETH MOHAN, MS, ${ }^{3}$ \\ ERICK VASQUEZ, MS, ${ }^{3}$ DAN SHIMKO, PhD,${ }^{3}$ WILLIAM McKAY, ME ${ }^{3}$ HYUN W. BAE, MD ${ }^{1}$ \\ ${ }^{I}$ Cedars-Sinai Medical Center, Los Angeles, California, ${ }^{2}$ Translational and Clinical Research, Spine Center, Cedars-Sinai Medical Center, Los Angeles, \\ California, ${ }^{3}$ Medtronic, Inc, Memphis, Tennessee
}

\begin{abstract}
Background: Insufficient data exist on bone graft substitute materials efficacy; two thirds lack any clinical data. ${ }^{1,2}$ This prospective animal study identified efficacy differences among commercially available materials of several classes.

Methods: Historically validated muscle pouch osteoinduction study (OIS) and posterolateral fusion (PLF) were performed in an athymic rat model. Grafting material products implanted were demineralized bone matrix (DBM)based allografts (Accell EVO3, DBX Mix, DBX Strip, Grafton Crunch, Grafton Flex, Grafton Matrix, Grafton Putty, Magnifuse, and Progenix Plus), allografts (OsteoSponge, MinerOss), cellular allograft (Osteocel Plus), ceramics (Mozaik Strip), or activated ceramics (Actifuse ABX Putty, Vitoss BA). After 4 weeks, OIS specimens were evaluated ex vivo by histologic osteoinductivity. After 8 weeks, PLF ex vivo specimens were evaluated for fusion by manual palpation $\left(\mathrm{F}_{\mathrm{MP}}\right)$, radiography $\left(\mathrm{F}_{\mathrm{XR}}\right)$, and histology $\left(\mathrm{F}_{\mathrm{HISTO}}\right)$.

Results: OIS: No materials exhibited a rejection reaction on histology. All DBM-based materials exhibited osteoinductive potential as new bone formation at $>88 \%$ of implanted sites. One plain allograft (OsteoSponge) formed bone at $25 \%$ of sites. No bone formed for one ceramic (Mozaik Strip), three activated ceramics (Actifuse ABX Putty), or one cellular allograft, regardless of human bone marrow aspirate (hBMA) when added. PLF: Among the 10 DBMs, 6 had $F_{\text {MP }}$ of 100\% (Accell EVO3, DBX Mix, DBX Strip, Grafton Flex, Grafton Putty, Magnifuse), 2 had $\mathrm{F}_{\mathrm{MP}}$ of $94 \%$ (Grafton Crunch, Grafton Matrix), and 2 conditions had $\mathrm{F}_{\mathrm{MP}}$ of $0 \%$ (Progenix Plus, Progenix Plus + athymic rat iliac crest bone graft [arICBG]). Ceramics (Mozaik Strip), activated ceramics (Actifuse ABX Putty, Vitoss BA), plain allograft (OsteoSponge, MinerOss (PLF study), and cellular allograft (Osteocel Plus) demonstrated $0 \% \mathrm{~F}_{\mathrm{MP}}$. ArICBG demonstrated $13 \% \mathrm{~F}_{\mathrm{MP}}$.

Conclusions: Eight DBM-based materials (Accell EVO3, DBX Mix, DBX Strip, Grafton Crunch, Grafton Flex, Grafton Matrix, Grafton Putty, Magnifuse) demonstrated excellent ( $>90 \% \mathrm{~F}_{\mathrm{MP}}$ ) efficacy in promoting fusion via bone healing. Two DBM conditions (Progenix Plus, Progenix Plus + arICBG) showed no manual palpation fusion ( $F_{M P}$ ). Systematically, over the 2 studies (OIS and PLF), cellular (Osteocel Plus), plain allografts (OsteoSponge, MinerOss; PLF study), ceramic (Mozaik Strip), and activated ceramics (Actifuse ABX Putty, Vitoss BA) demonstrated poor $\mathrm{F}_{\mathrm{MP}}$ efficacy $(<10 \%)$.

Clinical Relevance: When selecting DBMs, clinicians must be cognizant of variability in DBM efficacy by product and lot. While theoretically osteoinductive, cellular allograft and activated ceramics yielded poor in vivo efficacy. Whole allograft and ceramics may provide osteoconductive scaffolding for mixed-material grafting; however, surgeons should be cautious in using them alone. Direct clinical data are needed to establish efficacy for any bone graft substitute.
\end{abstract}

\section{Lumbar Spine}

Keywords: bone, bone grafts, substitute, expander, demineralized bone matrix (DBM), demineralized bone matrixbased products (DBM-based products), allografts, cellular allografts, autograft, ceramic, activated ceramic, bone morphogenetic protein, recombinant human bone morphogenetic protein, rhBMP, rhBMP-2, peptide, differentiation factor, posterolateral fusion, muscle pouch, rat model, rats, athymic rats

\section{INTRODUCTION}

Bone grafting has orthopedic applications within spine, oncology, trauma, and revision joint surgery; however, insufficient data exists on bone graft substitute materials efficacy. ${ }^{1-4}$ Annually, 185,000 US spinal fusions and 2 million worldwide grafting 
procedures are performed. ${ }^{5-9}$ Bone healing and fusion consolidation require an ordered cascade of initial inflammation, reparative ossification, and remodeling. ${ }^{4,10}$ Various grafting materials are employed to promote this bone healing process.

Iliac crest bone graft (ICBG) remains the gold standard graft. Autograft provides an osteoconductive scaffold, osteoinductive cellular chemoattractants, and osteogenic progenitor cells. However, autograft has drawbacks: potential harvest-related complications, limited volume, and poor bone quality in certain patients limits utility. ${ }^{4,11}$ The incidence of long-term pain following ICBG harvesting is from $2 \%$ to $25 \%$, increasing morbidity for back pain patients, who already represent $40 \%$ of opioid prescriptions. ${ }^{12-15}$

The American Academy of Orthopaedic Surgeons (AAOS) identified 63 bone graft substitutes, although many are used despite a lack of clinical evidence on their efficacy. ${ }^{2,16}$ Research continues to find the ideal substitute that would be "biocompatible, bioresorbable, osteoconductive, osteoinductive." Current options, discussed below, include whole and cellular allograft, ${ }^{2,17}$ demineralized bone matrix (DBM), hydroxyapatite (HA) and calcium ceramics/bioactive glasses, bone morphogenetic proteins (BMPs), and combinations of these.

\section{Ceramic and Synthetic Materials}

Used for decades, HA or tricalcium phosphates (TCP) grafts are available in many forms. They are cleared by the US Food and Drug Administration (FDA) for marketing on "substantial equivalence" to existing materials, without clinical efficacy data.

Silica, phosphate, and borate based bioactive glasses are in-development. ${ }^{10,18-20}$ These induce a hydroxycarbonate apatite surface layer for bone binding, and possibly create osteoinduction by solubilization of silica and calcium ions. ${ }^{21-23}$ However, clinical use is limited by brittleness causing low fracture strength and difficulty in synthesizing porous scaffolds.

\section{Allografts}

\section{Whole Allografts}

Whole allograft may be cortical or cancellous; incorporation is not as rapid or as reliable as autograft. $^{24}$ Disease transmission is rare, with no viral transmissions since $2002 .{ }^{10}$ Xenograft is similar but carries a higher risk of rejection. ${ }^{18}$

\section{Demineralized Bone Matrix-based Products}

DBM is created via acid extraction of the mineral components of allograft, leaving osteoconductive matrix with osteoinductive native BMPs. Their concentration varies among individual donor-based lots of the same product. ${ }^{7,25}$ Materials are heterogeneous, with different particle sizes and shapes, levels of demineralization and structure, and nonallograft additives for handling.

DBMs undergo different FDA regulatory paths depending on composition. Even in the most stringent path, "medical device," DBMs are cleared for marketing by demonstrating "substantial equivalence" to an existing device, without human efficacy trials (http://www.accessdata.fda.gov). ${ }^{26,27}$

\section{Cellular Allografts}

Cellular allograft provides mesenchymal or osteoprogenitor cells, often in DBM, for osteogenic grafting without autograft harvest. ${ }^{28-31}$ Processing methods vary, and immune response to this freshfrozen allograft is untested. These are distributed under Tissue Bank regulations; therefore, clinical efficacy trials are not required for marketing. ${ }^{32-34}$

\section{Growth Factors}

BMPs were described by Urist in the 1960s. ${ }^{35,36}$ BMP-2 is a growth factor involved in skeletal development and fracture healing. Recombinant human BMP-2 (rhBMP-2) is delivered via an absorbable collagen sponge (ACS). rhBMP-2 has experienced increased use in clinical practice, and has been discussed extensively in recent literature. $^{37-49}$

\section{Study Objectives}

Despite extensive clinical utilization of grafting adjuncts, there is little comparative efficacy data. Limited evidence suggests different DBMs facilitate different spinal fusion rates. ${ }^{1,50-52}$ Each material class also poses its own risks: including chronic pain from autograft harvest, rejection or disease transmission from allograft, and wound or neurologic complications with BMP. ${ }^{3,10,40,42}$ Better understanding of efficacy and osteoinductivity will help clinicians balance risk/benefit in grafting material selection.

The specific objectives of this study were to:

1. Screen for osteoinductivity and immunologic reaction of human and synthetic materials in 
athymic rats via an osteoinduction study (OIS).

2. Investigate in vivo fusion efficacy of bone graft substitutes via a posterolateral lumbar intertransverse fusion (PLF) study.

3. Understand comparative preclinical efficacy of material classes by including DBMs, whole and cell-based allograft, and plain and activated ceramics.

\section{MATERIALS AND METHODS}

The Institutional Animal Care Use Committee approved all procedures. Table 1 describes implant materials.

\section{Osteoinduction Study}

\section{Design}

Osteoinductivity of 16 materials was evaluated via rat intermuscular bone formation, listed in Tables 1 and 2.

\section{Subjects}

Sixty-eight athymic nude $\mathrm{rNu}^{-} \mathrm{rNu}^{-}$male rats (Harlan Laboratories, Indiana), 7- to 8-week-old, and 200 to 350 grams were used. Athymic nude rats minimize immune responses to the human derived materials.

\section{Materials}

DBM-based allografts (Accell EVO3, DBX Mix, DBX Strip, Grafton Crunch, Grafton Flex, Grafton Matrix, Grafton Putty, Magnifuse-loose, Magnifuse-pouch, and Progenix Plus), allograft (OsteoSponge), cellular allograft (Osteocel Plus), ceramics (Mozaik Strip with human bone marrow aspirate [hBMA]), activated ceramics (Actifuse ABX Putty, Vitoss BA Strip, Vitoss BA Strip with hBMA), or positive control conditions of 2 doses of rhBMP-2/ ACS $(0.1 \mathrm{mg} / \mathrm{mL}, 0.006 \mathrm{mg} / \mathrm{mL})$ were evaluated. All materials were prepared according to the manufacturer's instructions. Where indicated, heparinized fresh hBMA was added within 36 hours of hBMA harvest.

\section{Procedure}

Prophylaxis included buprenorphine for pain and ampicillin for infection (same as surgical description below). After general anesthesia and skin preparation, a small incision was made over the hind-limb. Then $0.2 \mathrm{~cm}^{3}$ of material was placed between muscular bundles, close to the femur but not touching bone, and wounds sutured closed. ${ }^{53-55}$

\section{Evaluation of Osteoinductivity}

At 4 weeks, rats were killed. Material-tissue explants were decalcified and paraffin embedded. Sections were hematoxylin and eosin (H\&E) stained. Osteoinductivity was a " 1 " indicating the presence of bone forming cells, cartilage, or new bone occupying a minimum of at least $5 \%$ of the implant area for $>50 \%$ of implanted sites; or a " 0 " indicating the absence of bone forming cells, chondrogenic activity, or new bone.

\section{Posterolateral Fusion}

\section{Design}

Bilateral 2-level posterolateral fusion (PLF) were performed at L3-L4-L5. Eight rats were implanted per each of 18 materials/conditions (Table 1). Positive controls employed were athymic rat ICBG (arICBG) as a gold standard ICBG equivalent and 2 doses of rhBMP-2/ACS $(0.1 \mathrm{mg} / \mathrm{mL}, 0.006 \mathrm{mg} / \mathrm{mL})$. Surgery alone (sham) was a negative control.

\section{Materials Evaluated}

DBM-based allografts (Accell EVO3, DBX Mix, DBX Strip, Grafton Crunch, Grafton Flex, Grafton Matrix, Grafton Putty, Magnifuse-pouch, and Progenix Plus, Progenix Plus + arICBG 50/50), allografts (OsteoSponge, MinerOss, MinerOss + arICBG 50/50), cellular allograft (Osteocel Plus), ceramics (Mozaik Strip + hBMA), activated ceramics (Actifuse ABX Putty, Vitoss BA Strip, Vitoss BA Strip Vitoss BA Strip +hBMA), or control conditions listed above.

Materials were prepared according to product instructions and applied in accordance with a previously generated randomization schedule. Rats were observed daily and killed at 8 weeks after surgery. Fusion assessments included manual palpation, radiography, and histopathology.

\section{Subjects}

One hundred eighty-four athymic $\mathrm{rNu}^{-} \mathrm{rNu}^{-}$male rats (Harlan Laboratories), 8 to 10 weeks old, were employed.

\section{Surgical Procedure}

All rats were weighed prior to surgery. Anesthesia, isoflurane/oxygen, was induced $(2 \%-4 \%)$ and maintained $(0.5 \%-2 \%)$ to effect. Buprenorphine 
Table 1. Description of implant materials.

\begin{tabular}{|c|c|c|c|}
\hline $\begin{array}{l}\text { Material Class and } \\
\text { Product Name }\end{array}$ & Manufacturer & Product Formulation & Manufacturer Description \\
\hline \multicolumn{4}{|c|}{ DBM-based product allograft } \\
\hline $\begin{array}{l}\text { Accell Evo3 DBM } \\
\text { Putty }\end{array}$ & Integra (Plainsboro, NJ) & Putty & $\begin{array}{l}\text { DBM mixed Accell Bone Matrix (ABM) is an open } \\
\text { structured, dispersed form of DBM, mixed with } \\
\text { poloxamer resorbable reverse phase medium with unique } \\
\text { thermo-reversible properties }\end{array}$ \\
\hline DBX Mix & Synthes (West Chester, PA) & $\begin{array}{l}\text { Putty combined with } \\
\text { cortical-cancellous } \\
\text { bone }\end{array}$ & $\begin{array}{l}\text { DBM granulated cortical bone in sodium hyaluronate, } \\
\text { provides morselized cortical-cancellous bone texture, } \\
\text { reduces need to combine bone chips with DBM }\end{array}$ \\
\hline DBX Strip & Synthes (West Chester, PA) & Preformed strips & $\begin{array}{l}\text { DBM granulated cortical bone in sodium hyaluronate } \\
\text { combined with gelatin provides a cohesive and flexible } \\
\text { consistency in a preformed strip formulation }\end{array}$ \\
\hline Grafton DBM Crunch & $\begin{array}{l}\text { Medtronic/BioHorizons } \\
\quad(\text { Minneapolis, MN) }\end{array}$ & $\begin{array}{l}\text { Putty combined with } \\
\text { demineralized cortical } \\
\text { cubes }\end{array}$ & $\begin{array}{l}\text { DBM wetted with USP anhydrous glycerol carrier with } \\
<6 \% \text { water by weight, }<5 \% \text { calcium by weight, } \\
\text { combination of demineralized bone fibers with } \\
\text { demineralized cortical cubes }\end{array}$ \\
\hline Grafton DBM Flex & $\begin{array}{l}\text { Medtronic/BioHorizons } \\
\text { (Minneapolis, MN) }\end{array}$ & Flexible sheets & $\begin{array}{l}\text { DBM wetted with USP anhydrous glycerol carrier with } \\
<6 \% \text { water by weight, }<5 \% \text { calcium by weight }\end{array}$ \\
\hline Grafton DBM Matrix & $\begin{array}{l}\text { Medtronic/BioHorizons } \\
\text { (Minneapolis, MN) }\end{array}$ & $\begin{array}{l}\text { Formed shapes, plugs, } \\
\text { strips }\end{array}$ & $\begin{array}{l}\text { DBM wetted with USP anhydrous glycerol carrier with } \\
<6 \% \text { water by weight, }<5 \% \text { calcium by weight }\end{array}$ \\
\hline Grafton DBM Putty & $\begin{array}{l}\text { Medtronic/BioHorizons } \\
\quad \mid(\text { Minneapolis, MN) }\end{array}$ & Putty & $\begin{array}{l}\text { DBM wetted with USP anhydrous glycerol carrier with } \\
<6 \% \text { water by weight, }<5 \% \text { calcium by weight }\end{array}$ \\
\hline Magnifuse DBM & $\begin{array}{l}\text { Medtronic/Osteotech } \\
\quad \text { (Minneapolis, MN) }\end{array}$ & Magnifuse & $\begin{array}{l}\text { Demineralized bone fibers with surface demineralized } \\
\text { cortical chips contained in resorbable macroporous } \\
\text { polyglycolic acid (PGA) mesh }\end{array}$ \\
\hline Progenix Plus DBM & $\begin{array}{l}\text { Medtronic/BioHorizons } \\
\text { (Minneapolis, MN) }\end{array}$ & $\begin{array}{l}\text { Putty with cortical } \\
\text { DBM powder and } \\
\text { demineralized cortical } \\
\text { chips }\end{array}$ & $\begin{array}{l}\text { DBM mixed with sodium alginate and type } 1 \text { bovine } \\
\text { collagen carrier hydrated with water, }<5 \% \text { calcium by } \\
\text { weight, demineralized cortical chips }\end{array}$ \\
\hline \multicolumn{4}{|l|}{ Allograft } \\
\hline OsteoSponge & Bacterin (Belgrade, MT) & $\begin{array}{l}\text { Malleable cancellous } \\
\text { bone }\end{array}$ & $\begin{array}{l}\text { Cancellous bone, provides a scaffold for cellular ingrowth } \\
\text { and exposes bone-growth-inducing proteins, malleable } \\
\text { properties enable it to fill irregular bony defects }\end{array}$ \\
\hline $\begin{array}{l}\text { MinerOss Cortical } \\
\text { and Cancellous }\end{array}$ & $\begin{array}{l}\text { Medtronic/BioHorizons } \\
\text { (Minneapolis, MN) }\end{array}$ & $\begin{array}{l}\text { Freeze-dried bone } \\
\text { allograft }\end{array}$ & $\begin{array}{l}\text { Mixture of cortical and cancellous chips provides limited } \\
\text { stability and space maintaining properties, forms an } \\
\text { osteoconductive scaffold }\end{array}$ \\
\hline \multicolumn{4}{|l|}{ Cellular Allograft } \\
\hline Osteocel Plus & NuVasive (San Diego, CA) & $\begin{array}{l}\text { DBM and cancellous } \\
\text { bone with retained } \\
\text { cells }\end{array}$ & $\begin{array}{l}\text { Cellular bone matrix containing mesenchymal stem cells and } \\
\text { osteoprogenitor cells combined with DBM and cancellous } \\
\text { bone, contains "cells, signals, and scaffold" }\end{array}$ \\
\hline \multicolumn{4}{|r|}{$\mathrm{cos}$} \\
\hline Mozaik Strip & Integra (Plainsboro, $\mathrm{NJ}$ ) & $\begin{array}{l}\text { Flexible compression- } \\
\text { resistant strip }\end{array}$ & $\begin{array}{l}20 \% \text { type I collagen blended with } 80 \% \text { high purity } \\
\text { tricalcium phosphate granules, developed to resemble the } \\
\text { composition of natural bone }\end{array}$ \\
\hline \multicolumn{4}{|l|}{ Activated Ceramic } \\
\hline Actifuse ABX Putty & Baxter (Deerfield, IL) & Flowable synthetic & $\begin{array}{l}\text { Phase-pure, porous, silicate substituted calcium phosphate } \\
\text { bone graft, granules in resorbable polymer matrix; } \\
\text { contains } 0.8 \% \text { silicon }\end{array}$ \\
\hline Vitoss BA Strip & Stryker (Kalamazoo, MI) & $\begin{array}{l}\text { Flexible compression- } \\
\text { resistant strip }\end{array}$ & $\begin{array}{l}\text { Beta-tricalcium phosphate formed into a } 90 \% \text { porous } \\
\text { scaffold, with silicate bioactive glass to produce the } \\
\text { deposition of a thin layer of biologically active calcium } \\
\text { phosphate }\end{array}$ \\
\hline
\end{tabular}

$(0.2-0.4 \mathrm{mg} / \mathrm{kg})$ for analgesia and ampicillin $(0.2 \mathrm{~mL}$ of $25 \mathrm{mg}$ Abraxis) for antimicrobial prophylaxis were administered subcutaneously. Area was cleaned of hair, an isopropyl alcohol rinse applied 3 times, and a povidone iodine surgical spray applied.

A 4- to 6-cm dorsal midline skin incision was made from L1 to L2 to the iliac crests. Twocentimeter paramedian incisions were made. Paraspinal musculature was retracted to expose the transverse processes (TPs) of L3 to L5 bilaterally, and then irrigated with $1.5 \mathrm{~mL}$ of normal saline. $\mathrm{L} 3$ to L5 TPs were decorticated bilaterally via motorized burr until bleeding bone was observed.

$0.6 \mathrm{~cm}^{3}$ of material was implanted each side over L3 to L5 TP bleeding bone as shown in Appendix 1 $\left(1.2 \mathrm{~cm}^{3}\right.$ implant per animal). For sham surgery, TPs were decorticated with no material implanted.

Two-layer closure was performed using monofilament polyglyconate (4-0 Maxon, Tyco Healthcare). 


\begin{tabular}{|c|c|c|}
\hline Screening and Sterilization & Manufacturer Stated Testing & Regulations \\
\hline $\begin{array}{l}\text { Donor screening, serological testing, viral } \\
\text { inactivation, electron beam irradiation }\end{array}$ & $\begin{array}{l}\text { Lots tested in vitro prior to formulating final } \\
\text { product }\end{array}$ & FDA: K103742 \\
\hline $\begin{array}{l}\text { Donor screening, serological testing, } \\
\text { USP71 sterility testing }\end{array}$ & $\begin{array}{l}\text { Lots tested via athymic mouse muscle pouch } \\
\text { assay and alkaline phosphatase assay }\end{array}$ & FDA: K053218, K080399, K040262 \\
\hline $\begin{array}{l}\text { Donor screening, serological testing, } \\
\text { USP71 sterility testing }\end{array}$ & $\begin{array}{l}\text { Lots tested via athymic mouse muscle pouch } \\
\text { assay and alkaline phosphatase assay }\end{array}$ & FDA: K062205, K042829, K121313 \\
\hline $\begin{array}{l}\text { Donor screening, serological testing, viral } \\
\text { inactivation, USP71 sterility testing }\end{array}$ & $\begin{array}{l}\text { Final product lots tested for osteoinductivity via } \\
\text { athymic rat model }\end{array}$ & FDA: K051188, K051195 \\
\hline $\begin{array}{l}\text { Donor screening, serological testing, viral } \\
\text { inactivation, USP71 sterility testing }\end{array}$ & $\begin{array}{l}\text { Final product lots tested for osteoinductivity via } \\
\text { athymic rat model }\end{array}$ & FDA: K051188, K051195 \\
\hline $\begin{array}{l}\text { Donor screening, serological testing, viral } \\
\text { inactivation, USP71 sterility testing }\end{array}$ & $\begin{array}{l}\text { Final product lots tested for osteoinductivity via } \\
\text { athymic rat model }\end{array}$ & FDA: K051188, K051195 \\
\hline $\begin{array}{l}\text { Donor screening, serological testing, viral } \\
\text { inactivation, USP71 sterility testing }\end{array}$ & $\begin{array}{l}\text { Final product lots tested for osteoinductivity via } \\
\text { athymic rat model }\end{array}$ & FDA: K051188, K051195 \\
\hline $\begin{array}{l}\text { Donor screening, serological testing, viral } \\
\text { inactivation, USP71 sterility testing }\end{array}$ & $\begin{array}{l}\text { Final product lots tested for osteoinductivity via } \\
\text { athymic rat model }\end{array}$ & FDA: K082615, K122513 \\
\hline $\begin{array}{l}\text { Donor screening, serological testing, viral } \\
\text { inactivation, electron beam irradiation }\end{array}$ & $\begin{array}{l}\text { Final product lots tested for osteoinductivity via } \\
\text { athymic rat model }\end{array}$ & $\begin{array}{l}\text { FDA: K072265, K082463, K082002, } \\
\text { K081950, K080462 }\end{array}$ \\
\hline $\begin{array}{l}\text { Low-dose gamma irradiation, BacteRinse } \\
\text { sterilization }\end{array}$ & $\begin{array}{l}\text { Final product lots tested for osteoinductivity in } \\
\text { an animal model }\end{array}$ & AATB guidelines \\
\hline $\begin{array}{l}\text { Screened donors, serological testing, viral } \\
\text { inactivation }\end{array}$ & $\mathrm{N} / \mathrm{A}$ & AATB guidelines \\
\hline $\begin{array}{l}\text { Screened donors, serological testing, viral } \\
\text { inactivation, antimicrobial treatment }\end{array}$ & Each lot screened for presence of active cells & AATB guidelines \\
\hline $\mathrm{N} / \mathrm{A}$ & $\mathrm{N} / \mathrm{A}$ & FDA: K141841, K091302, K063124 \\
\hline $\mathrm{N} / \mathrm{A}$ & $\mathrm{N} / \mathrm{A}$ & $\begin{array}{l}\text { FDA: K090850, K082575, K081979, } \\
\text { K082073 }\end{array}$ \\
\hline $\mathrm{N} / \mathrm{A}$ & $\mathrm{N} / \mathrm{A}$ & $\begin{array}{l}\text { FDA: K103173, K083033, K081439, } \\
\text { K072184 }\end{array}$ \\
\hline
\end{tabular}

\section{Materials Preparation and Implant Conditions}

Materials were prepared according to the manufacturer's instructions. Where indicated, heparinized fresh hBMA was added within 36 hours of harvest (Lonza; http://www.lonza.com/products-services/ bio-research/primary-cells/hematopoietic-cells/ unprocessed-bone-marrow.aspx gclid $=\mathrm{CLWm} 4 \mathrm{Lb}$ K38UCFUo6gQodbH8ATQ).

Allograft: Particles of a DBM-based material (Magnifuse) and a cellular allograft (Osteocel) were aseptically scaled down using a rongeur to approx- imately $1 \mathrm{~mm}^{3}$ particles (accommodate to smaller size of fusion site in the rat).

Athymic rat ICBG: Iliac crest was aseptically harvested from donor athymic rats, rongeur morselized to 2 to $3 \mathrm{~mm}^{3}$, and used within 4 hours of harvest.

rhBMP-2/ACS: $2 \times 2.9 \times 0.35 \mathrm{~cm}$ of ACS carrier was loaded with concentration of $0.006 \mathrm{mg} / \mathrm{mL}$ or $0.1 \mathrm{mg} / \mathrm{mL}$ rhBMP-2 solution at 15 minutes prior to implantation (1.2 $\mathrm{cm}^{3}$ solution per animal). 
Table 2. Osteoinductivity study.

\begin{tabular}{|c|c|c|c|c|c|}
\hline \multicolumn{2}{|c|}{ Description } & \multicolumn{2}{|c|}{ Design } & \multicolumn{2}{|l|}{ Results } \\
\hline Type of Material Group & Name & Lots & $\mathbf{n}$ & $\begin{array}{l}\text { Samples With Any Histologic Osteoinductivity } \\
\text { (Sites With Bone Formation)/(Total Sites) }\end{array}$ & $\begin{array}{l}\text { Coefficient of Variation } \\
\text { (CV) Percentage }\end{array}$ \\
\hline Control-differentiation factor & rhBMP-2 (0.006 mg/mL) & 1 & 4 & $4 / 4$ & $\mathrm{~N} / \mathrm{A}$ \\
\hline Control-differentiation factor & rhBMP-2 $(0.1 \mathrm{mg} / \mathrm{mL})$ & 1 & 4 & $4 / 4$ & $\mathrm{~N} / \mathrm{A}$ \\
\hline DBM & Accell Evo3 & 3 & 12 & $4 / 4,4 / 4,4 / 4$ & 0 \\
\hline DBM & DBX Mix & 2 & 8 & $3 / 4,4 / 4$ & 20 \\
\hline DBM & DBX Strip & 3 & 12 & $4 / 4,4 / 4,4 / 4$ & 0 \\
\hline DBM & Graft on Crunch & 3 & 12 & $4 / 4,4 / 4,4 / 4$ & 0 \\
\hline DBM & Graft on Flex & 2 & 8 & $4 / 4,4 / 4$ & 0 \\
\hline DBM & Graft on Matrix & 3 & 12 & $3 / 4,4 / 4,4 / 4$ & 16 \\
\hline DBM & Graft on Putty & 3 & 12 & $4 / 4,4 / 4,4 / 4$ & 0 \\
\hline DBM & Magnifuse (loose material) & 1 & 4 & $4 / 4$ & $\mathrm{~N} / \mathrm{A}$ \\
\hline DBM & Magnifuse (in pouch) & 1 & 4 & $4 / 4$ & $\mathrm{~N} / \mathrm{A}$ \\
\hline DBM & Progenix Plus & 3 & 12 & $4 / 4,3 / 4,4 / 4$ & 16 \\
\hline Allograft & OsteoSponge & 1 & 4 & $1 / 4$ & $\mathrm{~N} / \mathrm{A}$ \\
\hline Cellular Allograft & Osteocel Plus & 3 & 12 & $0 / 4,0 / 4,0 / 4$ & 0 \\
\hline Ceramic & Mozaik Strip + hBMA & 1 & 4 & $0 / 4$ & $\mathrm{~N} / \mathrm{A}$ \\
\hline Activated Ceramic & Actifuse ABX Putty & 1 & 4 & $0 / 4$ & $\mathrm{~N} / \mathrm{A}$ \\
\hline Activated Ceramic & Vitoss BA Strip & 1 & 4 & $0 / 4$ & $\mathrm{~N} / \mathrm{A}$ \\
\hline Activated Ceramic & Vitoss BA + hBMA & 1 & 4 & $0 / 4$ & $\mathrm{~N} / \mathrm{A}$ \\
\hline
\end{tabular}

\section{Postsurgical Care and Sacrifice}

Rats were singly housed in sanitized cages. Analgesic (buprenorphine) and antibiotic (ampicillin or amoxicillin) was administered PRN. At 8 weeks, $\mathrm{CO}_{2}$ euthanasia was performed. Caudal thoracic vertebrae to the sacrum spine segments were explanted.

\section{Evaluation}

Fusion as Determined by Manual Palpation. Two blinded independent observers palpated for motion by applying a bending moment at individual L3 to L4, L4 to L5 interspaces by grasping each vertebral body between thumb and index finger. Coronal then sagittal forces were applied with motion directly visualized. Unit of observation was individual level, graded as fused if "no motion" (fusion) seen at either side. This technique has been well correlated with rigidity on biomechanical testing. ${ }^{17,56-58}$

Fusion as Determined by Radiographs. Fusion as determined by radiographs: In vivo radiographs were performed postoperatively and at 4 weeks. At 8 weeks, high resolution ex vivo radiographs (Faxitron, Tucson, Arizona) were taken. Radiographs were reviewed by the veterinarian and 2 blinded independent observers. Complete bridging bone traversing the implant area without radiolucency was determined as fused.

Fusion as Determined by Histology. Tissue blocks were decalcified and embedded in paraffin. Spine segments L2 to L6 were bisected bilaterally. Serial histological sections in the sagittal plane were H\&E stained. Sections were evaluated for fibroplasia, bone matrix, residual implant material, cartilage matrix, and marrow.

\section{Statistical Analysis}

PLF: For manual palpation fusion $\left(\mathrm{F}_{\mathrm{MP}}\right)$ and radiographic fusion $\left(\mathrm{F}_{\mathrm{XR}}\right)$, each was calculated as percent of fused spinal levels over total levels implanted per material. Ninety-five percent exact confidence intervals (CIs) were calculated. Histologic fusion $\left(\mathrm{F}_{\text {HISTO }}\right.$ ) was calculated as percent of fused right and left sides over total sides implanted per material. Intrarelationships among dependent variables $\left(\mathrm{F}_{\mathrm{MP}}, \mathrm{F}_{\mathrm{HISTO}}, \mathrm{F}_{\mathrm{XR}}\right)$ were examined by Spearman correlation coefficients by material with significance if $P<0.05$.

OIS: These data are the sites showing osteoinductivity divided by the total implanted sites. The coefficient of variation $(\mathrm{CV} \%)$ was calculated when $>1$ unique lot was tested per material. For frequency data, the Fisher's exact test was used.

\section{RESULTS}

All animals tolerated the OIS $(n=68)$ and PLF procedures $(n=184)$ and gained weight, with no adverse events.

\section{Osteoinductivity Study}

The DBMs (Accell EVO3, DBX Mix and Strip, Grafton Crunch, Flex, Matrix and Putty, Magnifuse, and Progenix) all exhibited positive osteoin- 
ductive potential. Allografts (OsteoSponge, Osteocel), and ceramics (Actifuse ABX Putty, Mozaik Strip with hBMA, Vitoss $\mathrm{BA} \pm \mathrm{hBMA}$ ) failed to exhibit osteoinductivity. Lot-to-lot variability was $\leq 20 \%$ for materials with $\geq 2$ lots tested. See Table 2 .

\section{PLF Study}

For $F_{M P}, F_{X R}$, and $F_{\text {HISTO }}$ outcomes, see Figure 1 and data presented in Appendix 2. Figure 2 presents radiographs of radiodense materials that appear on $\mathrm{x}$-ray but with $0 \% \mathrm{~F}_{\mathrm{MP}}$. Figures 3 to 10 present high-resolution ex vivo radiographs paired with decalcified histologic sections. The sections were $H \& E$ stained and had original magnifications of $\times 4$ to $\times 7$. Examples were subjectively selected as the best two in class and the single worst in class. When a single rat is described, it is labeled as "\#<sample number $>$ ", with " $R$ " or " $L$ " for right or left side if relevant.

\section{Manual Palpation Fusion}

At 8 weeks, $88 \%$ to $100 \%$ of levels fused with DBM-based products (Accell Evo3, DBX Mix and Strip, Grafton Crunch, Grafton Flex, Grafton Matrix [two lots, 16/16, 14/16] with both unfused levels in 1 rat, and Grafton Putty, and Magnifuse). No levels manually fused $(0 / 16)$ with DBMs containing bovine collagen + natural polysaccharide/sodium alginate (Progenix Plus \pm arICBG), plain allografts (OsteoSponge, MinerOss, MinerOss \pm arICBG), cellular allograft (Osteocel), ceramics or activated ceramics (Actifuse ABX Putty, Vitoss BA \pm hBMA, Mozaik Strip with hBMA), or sham surgery. All levels fused (16/16) with 0.006 and $0.1 \mathrm{mg} / \mathrm{mL}$ rhBMP-2/ACS; wrong level surgery recorded when L2 to L4 palpably fused instead of L3 to L5 in a rat implanted with $0.006 \mathrm{mg} / \mathrm{mL}$ (rat \#670, levels confirmed with radiograph). Thirteen percent fusion occurred with arICBG $(2 / 16)$.

\section{Radiography}

At 8 weeks, $88 \%$ to $100 \%$ of levels radiographically fused with DBM-based products (Accell EVO3 [14/ 16], DBX Mix [16/16], DBX Strip [16/16], Grafton Crunch [15/16], Grafton Flex [16/16], Grafton Matrix [16/16, 14/16], Grafton Putty [14/16], and Magnifuse [16/16]). Although radiographically fused, bone fragment remodeling was observed in radiographs for several DBMs (DBX Mix [16/16], Figure 6; Magnifuse [16/16], Figure 7). Twenty-five percent of levels radiographically fused with DBMbased product containing sodium alginate (Progenix Plus + arICBG [4/16]; possibly over-called as $\mathrm{F}_{\mathrm{MP}}$ was $0 \%)$. No radiographic fusion $(0 / 16)$ was seen for plain allografts (OsteoSponge, MinerOss \pm arICBG) or cellular allograft (Osteocel); TP sites had apparent density yet no remodeling on 8week radiographs compared with postoperative radiographs. No sites radiographically fused $(0 / 16)$ for ceramics (Actifuse ABX Putty, Mozaik Strip with hBMA, Vitoss BA \pm hBMA), showing significant mineralized implant material, a lack of interconnectivity between the radiodense areas and host TPs, and an unclear difference between 4- and 8-week radiographic images (Figures 2, 7, 9, and 10).

Only $6 \%$ levels fused $(1 / 16)$ with arICBG; radiodense chips and few areas of remodeling were observed in 8-week radiographs. One hundred percent levels $(16 / 16)$ radiographically fused with $0.006 \mathrm{mg} / \mathrm{mL} / \mathrm{ACS}$ and $0.1 \mathrm{mg} / \mathrm{mL} \mathrm{rhBMP}-2 / \mathrm{ACS}$.

There was no radiodensity in sham surgery sites (0/16; Figure 4).

\section{Histopathology}

Histological evaluation revealed no adverse findings, evidence of tissue rejection, or poor biocompatibility in any of the study groups. Details are presented in Figures 3 to 10.

\section{Summary of Relationships-Posteriorlateral Fusion Study}

Measures of $\mathrm{F}_{\mathrm{MP}}, \mathrm{F}_{\mathrm{XR}}$, and $\mathrm{F}_{\mathrm{HISTO}}$ were positively interrelated $\left(\mathrm{F}_{\mathrm{MP}}\right.$ versus $\mathrm{F}_{\mathrm{XR}}, r=0.90, P<0.0001$; $\mathrm{F}_{\mathrm{MP}}$ versus $\mathrm{F}_{\mathrm{HISTO}}, r=0.89, P<0.0001$; and $\mathrm{F}_{\mathrm{XR}}$ versus $\left.\mathrm{F}_{\text {HISTO }}, r=0.91, P<0.0001\right)$. Histologic fusion $\left(\mathrm{F}_{\text {HISTO }}\right)$ was positively related to percent new bone $\left(\%_{\text {BONE }}\right)$ with $r=0.66(P<0.0008)$ and negatively related to percent fibrous tissue (\% \% Fibrous) with $r=-0.79$ ( $P<0.0001)$. Manual palpation fusion $\left(\mathrm{F}_{\mathrm{MP}}\right)$ was also positively correlated with percent new bone ( $\%_{\text {BONE }}, r=0.4$, $P<0.0001)$ and inversely correlated with percent fibrous tissue ( $\%$ Fibrous, $r=-0.83, P<0.0001$ ) and percent residual graft $(\%$ RESIDUAL,$r=-0.42$, $P<0.0497)$.

Osteoinductivity results (OIS) and manual testing fusion (PLF) results were significantly positively correlated across materials tested in spite of differing lots $(r=0.72, P<0.002,16$ common test materials between OIS and PLF). Two exceptions 


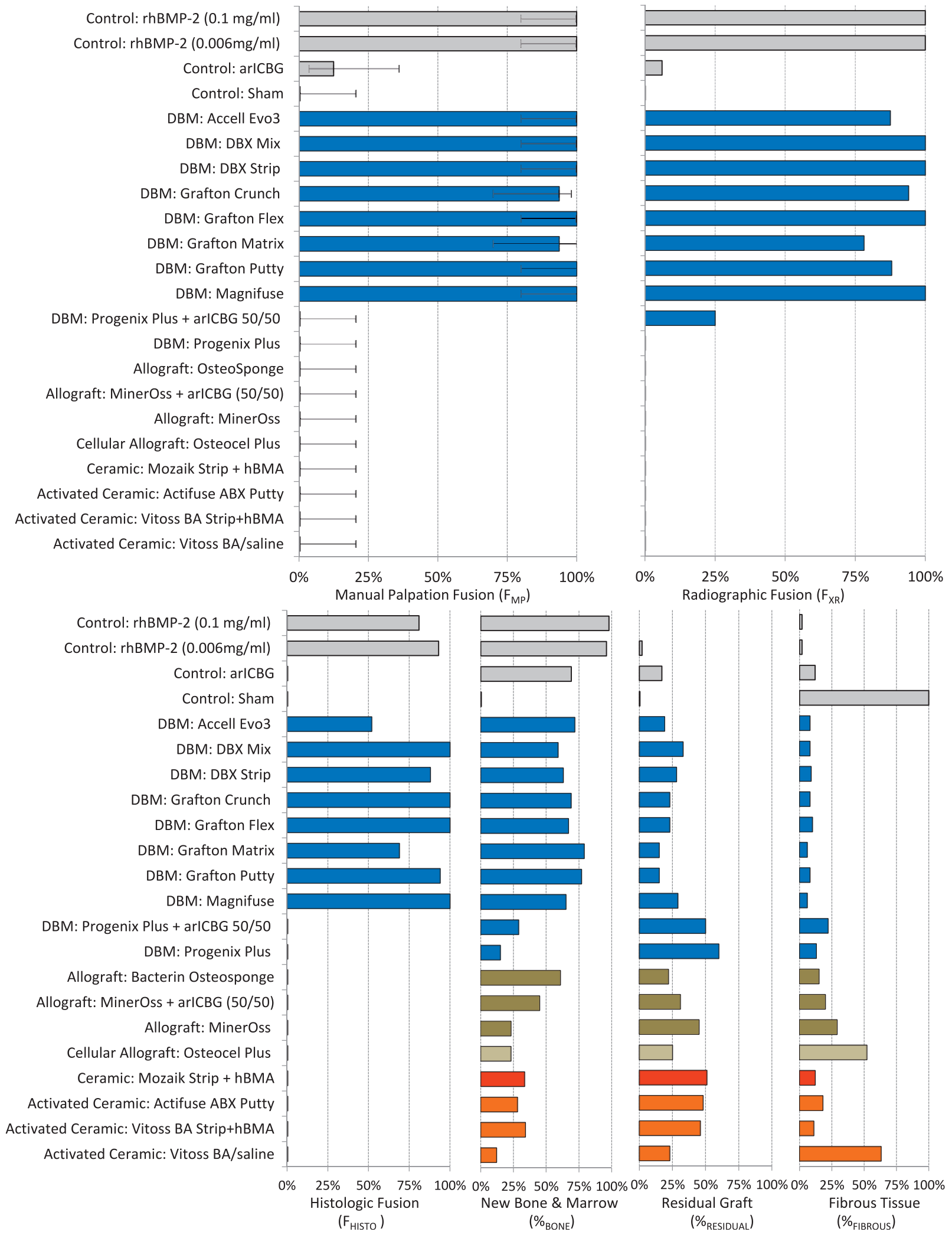

Figure 1. Upper graphs show percent fusion rate by manual palpation $\left(F_{M P}\right)$ and radiography $\left(F_{X R}\right)$; lower graphs show percent fusion rate by histology $\left(F_{H I S T O}\right)$, as well as histologic analysis of average percentage of new bone and marrow formation (\% $\%_{\text {BONE }}$ ), residual graft (\%RESIDUAL), and fibrous tissues (\% \% FBROus) in the implant area, ex vivo at 8 weeks after PLF. Except for Progenix Plus (0\%), $\mathrm{F}_{\mathrm{MP}}$ for DBMs (100\% [Cl: $80 \%-100 \%$ ]; $94 \%$ [Cl: $71 \%-98.5 \%$ ]) was greater than that for allografts and cellular allografts, ceramics, and activated ceramics $(0 \%)$. Excluding Progenix Plus, $\mathrm{F}_{\mathrm{MP}}$ was not significantly different among DBMs and rhBMP-2 (at 0.006 and $0.1 \mathrm{mg} / \mathrm{mL}$ concentrations). Histologic analysis is correlated with fusion rates as discussed in the Results section. 
occurred, with 1 DBM-based product (Progenix Plus) and 1 plain allograft (OsteoSponge) showing positive osteoinductivity in the OIS with poor manual palpation fusion $\left(\mathrm{F}_{\mathrm{MP}}\right)$ in the PLF study.

\section{DISCUSSION}

Successful union after a multilevel instrumented spinal fusion procedure is a clinical challenge that usually necessitates use of graft extenders. Novel biomaterials, bone grafting substitutes, and adjuvants are rapidly designed and launched without proven preclinical efficacy (recent clinical review and updated guidelines). ${ }^{2}$ In order to address this, we present radiographic and histological images for each individual material tested. Individual growth factors and DBMs have been studied with similar methods. ${ }^{7,11,17,25,48,50-52,59-64}$ However, none compared multiple DBMs, whole and cellular allografts, and ceramics and activated ceramics. Our data provide the most comprehensive comparative efficacy evaluation of fusion adjuncts in an athymic rat model to date. Unlike prior single-level athymic rat studies, a 2-level fusion procedure was used, ${ }^{17,50,65,66}$ allowing efficacy assessment in multilevel fusions similar to commonly performed clinical spine surgery.

\section{Ceramics and Activated Ceramics}

These ceramics resulted in insufficient in vivo ossification for manual palpation fusion $\left(\mathrm{F}_{\mathrm{MP}}\right)$, with $73 \%$ average residual graft and fibrous tissue on histology. No ceramics have shown in vivo osteoinductive effects; some literature recommends using these only as graft extenders, not solo grafts. ${ }^{2,23,66}$ The lack of a ceramic + arICBG mix graft in this study may negatively bias results, as this combination may be attempted clinically. However, as the ceramic + hBMA group failed to fuse, this suggests hBMA does not substitute for autologous bone graft with ceramics.

Ceramics and activated ceramics have demonstrated mixed success in rabbits. Clinical studies may have had radiographic outcomes biased by residual, radiopaque residual graft. ${ }^{2,67}$ Ceramics are likely best suited for cancellous sites where osteoprogenitor cells are already available. ${ }^{67-72}$

\section{Allografts}

\section{Whole and Cellular}

Osteocel cell-based allograft material failed to fuse. The ability of fat and marrow derived stem cells to

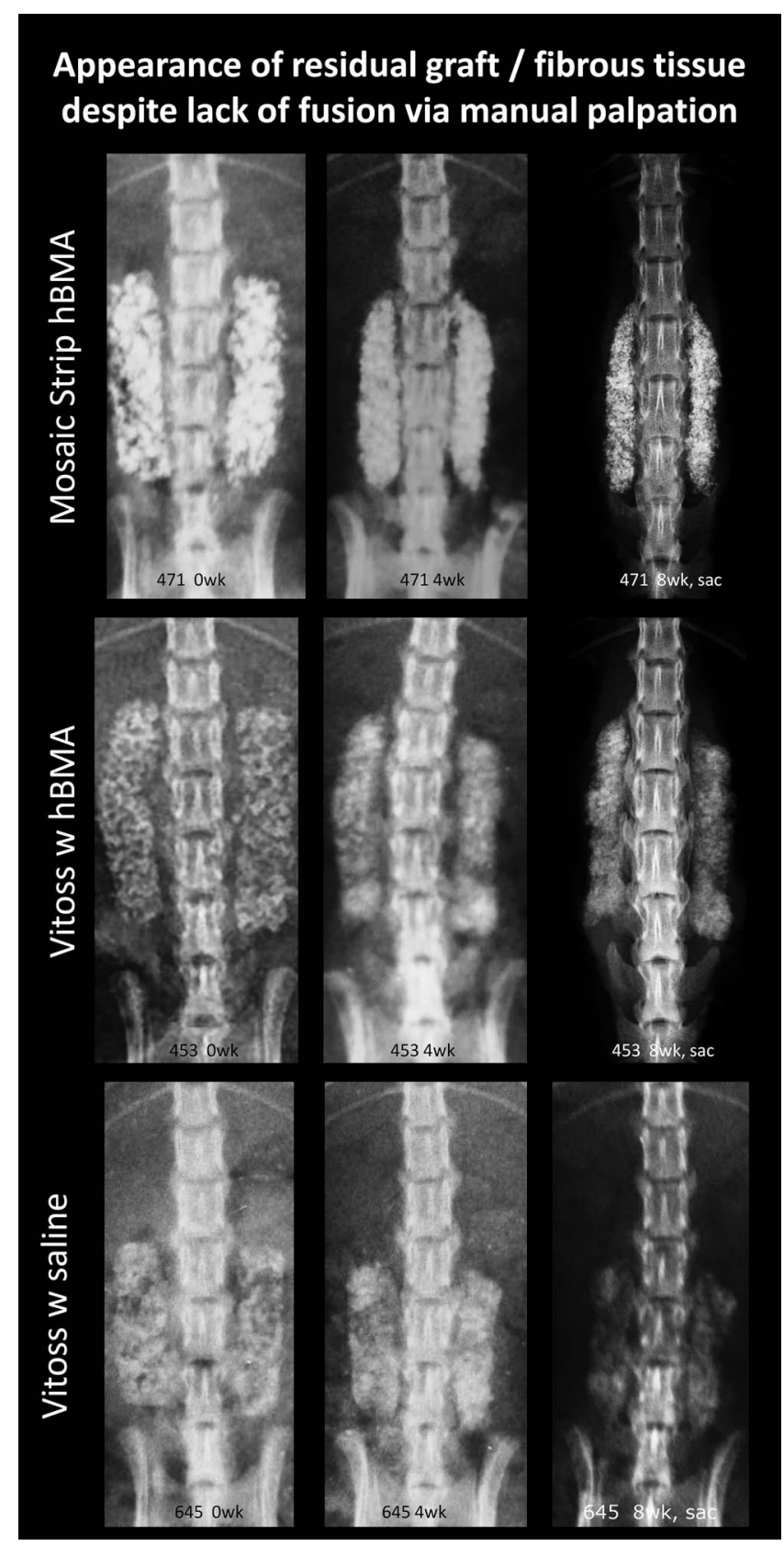

Figure 2. Selected in vivo radiographs of rats at 0-, 4-, and 8-week time points with radiodense materials having $\mathrm{F}_{\mathrm{MP}}$ of $0 \%$. Despite the lack of fusion as determined by manual palpation $\left(\mathrm{F}_{\mathrm{MP}}\right)$ and histology $\left(\mathrm{F}_{\text {HISTO }}\right)$, these ceramic and activated ceramic materials have high radiodensity that mimics a fusion mass on radiography. Multifocal changes to the radiodensity pattern from 0 to 8 weeks suggest remodeling activity. Careful radiographic review is necessary to note the transverse radiolucent fissures and lack of continuous bone bridges.

survive in athymic nude mice has been shown. ${ }^{60,73}$ Also, other human-derived tissues function in this animal model ${ }^{74,75}$; however, this rodent model may not be a reliable and valid test of this class of grafting materials. DBM containing viable cells (Trinity Evolution Orthofix) failed to induce rigid fusions in athymic rats in another study as well. ${ }^{76}$ Results herein suggest a poor osteogenic effect for 


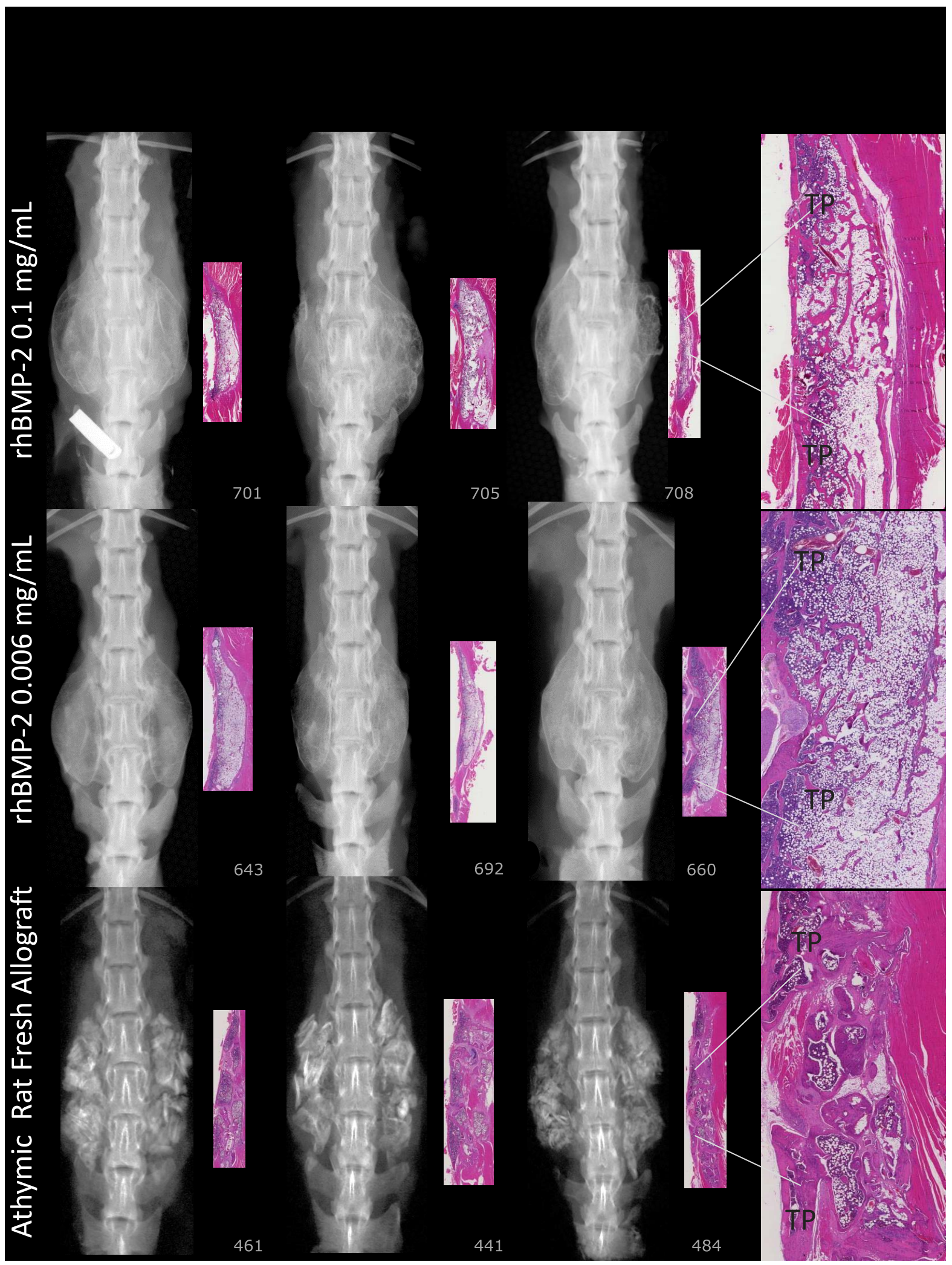

Figure 3. Bilateral robust mineralized fusion masses span $L 3$ to $L 5(0.1 \mathrm{mg} / \mathrm{mL}$ rhBMP-2/ACS). Radiography shows uniform density with defined margins demonstrating formed bone with cortex $(0.006 \mathrm{mg} / \mathrm{mL}$ rhBMP-2/ACS). Number 692: histology shows a thin tract of wispy basophilic material (scored as residual material with mineralization) infiltrated with fibrous connective tissue and a few multinucleated giant cells. Radiography shows a fusion region with a thin rim of lamellar bone that forms a complete border continuous with TPs L3 to L4 to L5. Number 660: on histology the fusion is robust with lamellar bone continuous with L3 to L4 to L5 TPs. Trabeculae near TPs are mildly robust, and some portions of the mass are devoid of trabeculae. Particulate dense mineral exists in the L3 to L4 to L5 TP interspaces on radiography (arlCBG). Histology shows $69 \%$ new bone and marrow formation, suggesting bioactivity and early remodeling. 


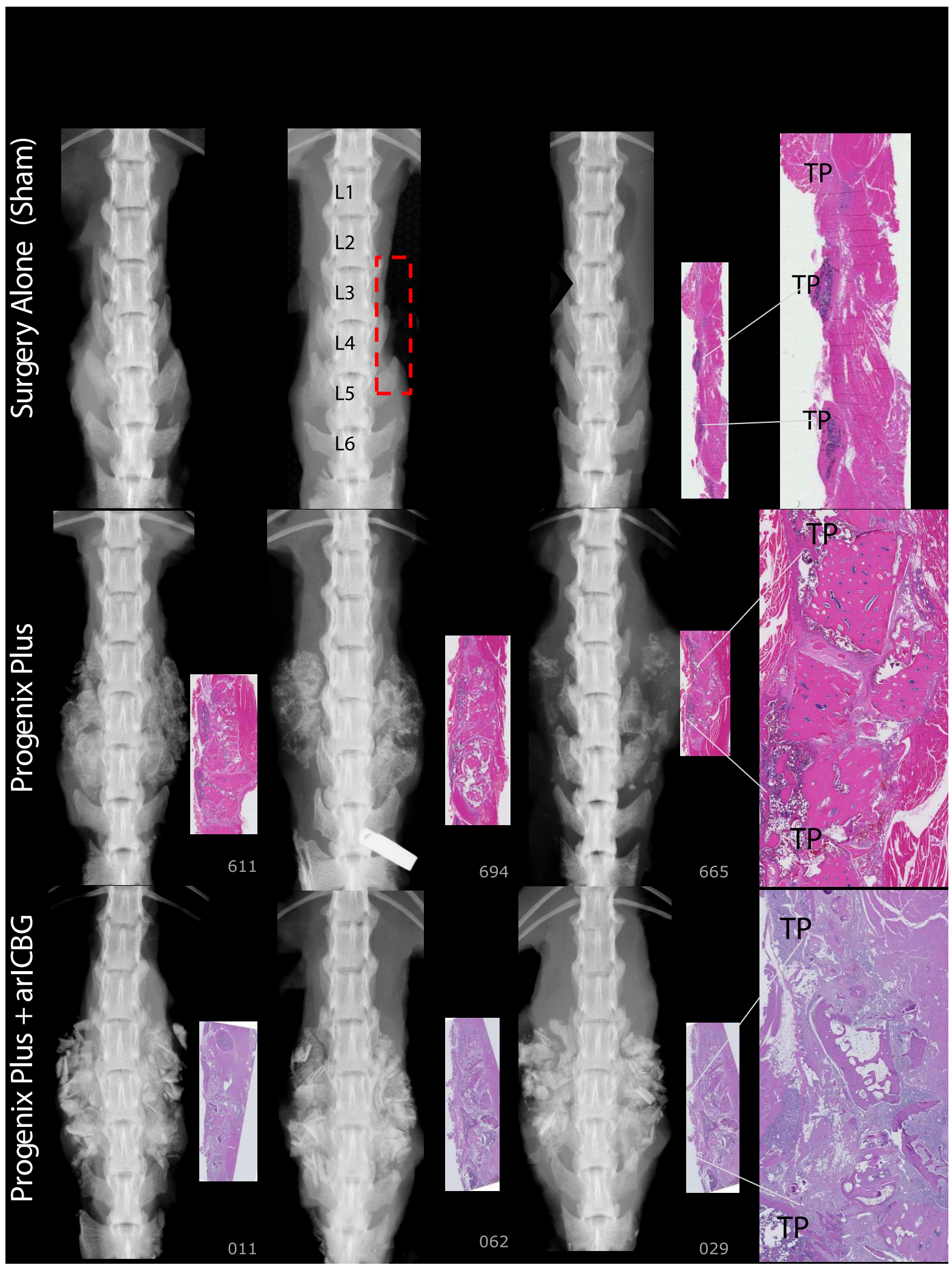

Figure 4. Surgery Alone (Sham): No dense mineral exists in the TPs interspace of $L 3$ to $L 4$ to $L 5$ regions of interest (ROI), outlined in red rectangle on radiographic image. Paired histology indicates TP interspaces filled with fibrous tissues. Progenix Plus: No evidence of fusion on histology; exhibits variably sized bony residual implant pieces, encapsulated with fibrous connective tissue. There are scattered regions of mineralization in the fibrotic areas. Radiography and histology show limited foci of lamellar bone extending from TP. Progenix Plus + arlCBG, numbers 029 and 062: No evidence of fusion on histology, and demonstrates large pieces of residual implant material surrounded by fibrous tissue. Trabeculae are sparse, with little evidence of connections. Areas of fatty marrow show basophilic staining consistent with saponified fat. 


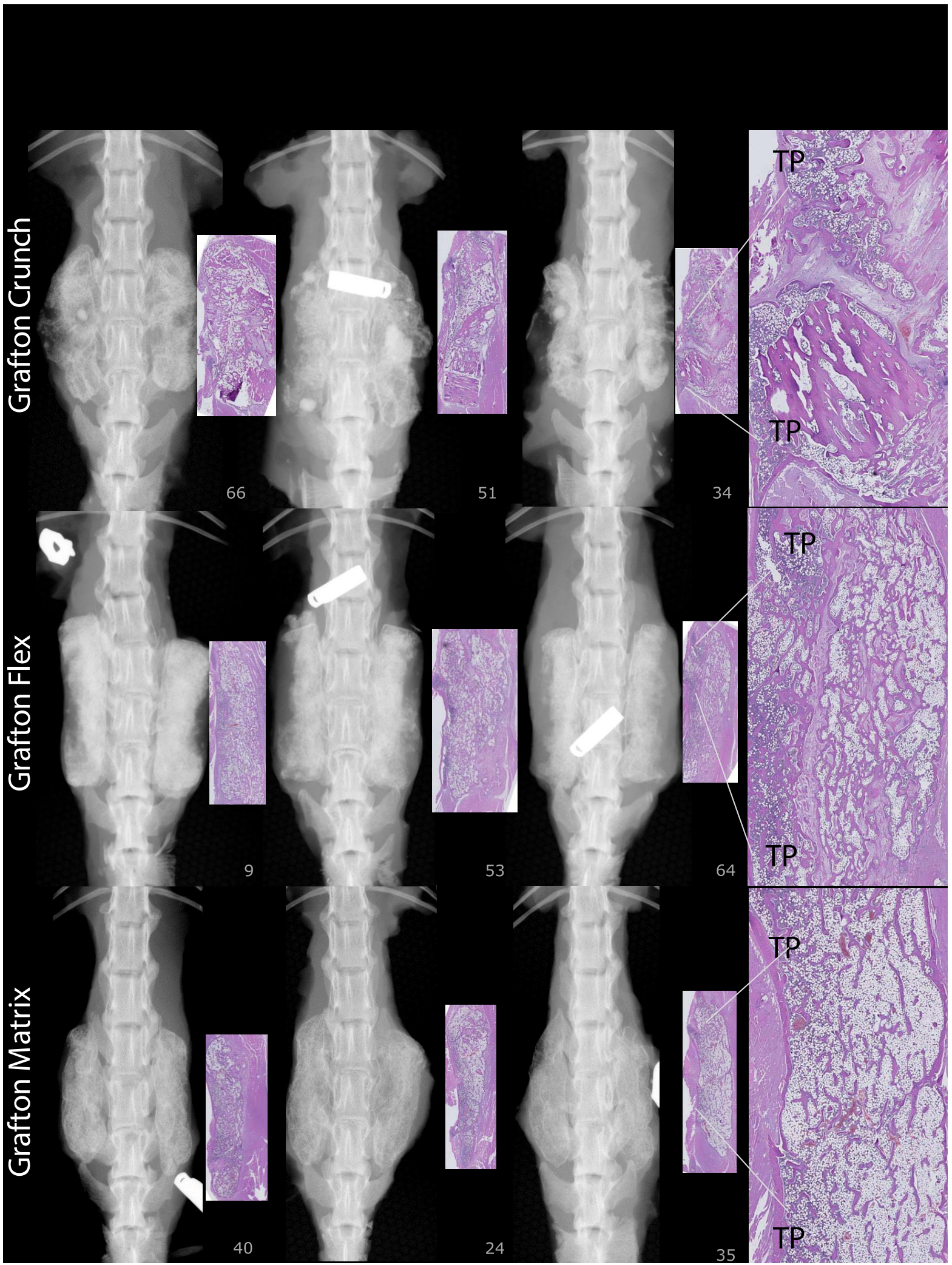

Figure 5. Grafton-Crunch: Histology shows $65 \%$ new bone, with uniform spacing and orientation of lamellar trabeculae, and bony union across TP interspaces with connectivity to TPs L3 to L4 to L5. Number 034: Residual graft (RG) from implanted material. Grafton-Flex, number 009: Robust trabeculae and marrow areas connecting to 3 TPs. Number 064: Evidence of bony union across TP interspaces; however, RG is present. Grafton-Matrix: Histology shows a large amount of lamellar bone with regular sized trabeculae, oriented relatively uniformly throughout the implant area and connected to TPs, $79 \%$ new bone. 


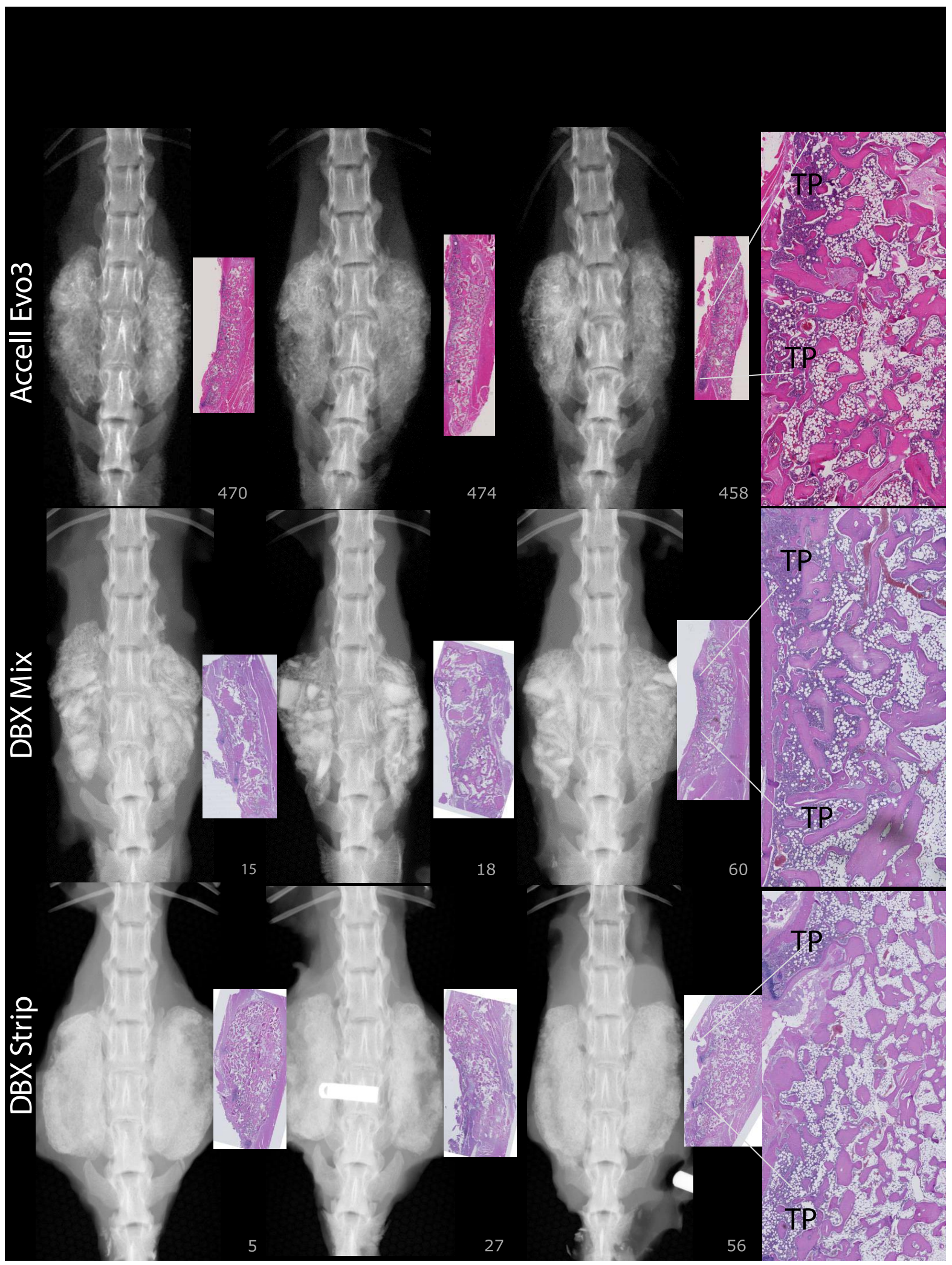

Figure 6. Accell Evo3: Histology demonstrates trabecular and lamellar bone with low residual implant material and $72 \%$ new bone. DBX Mix: Histology shows irregularly shaped but robust trabeculae are laced between implant pieces throughout the implant area with continuous cortex and connectivity with TPs. Some regions are devoid of trabecular bone. Most demonstrate an outer rim of lamellar bone. DBX Strip: Trabeculae are generally robust; however, many regions demonstrate partial residual graft as short trabeculae without viable osteocytes. Number 027: Tenuous fusion due to clumped pieces of implant material surrounded by fibrosis. Some sections have an outer rim of lamellar bone. 


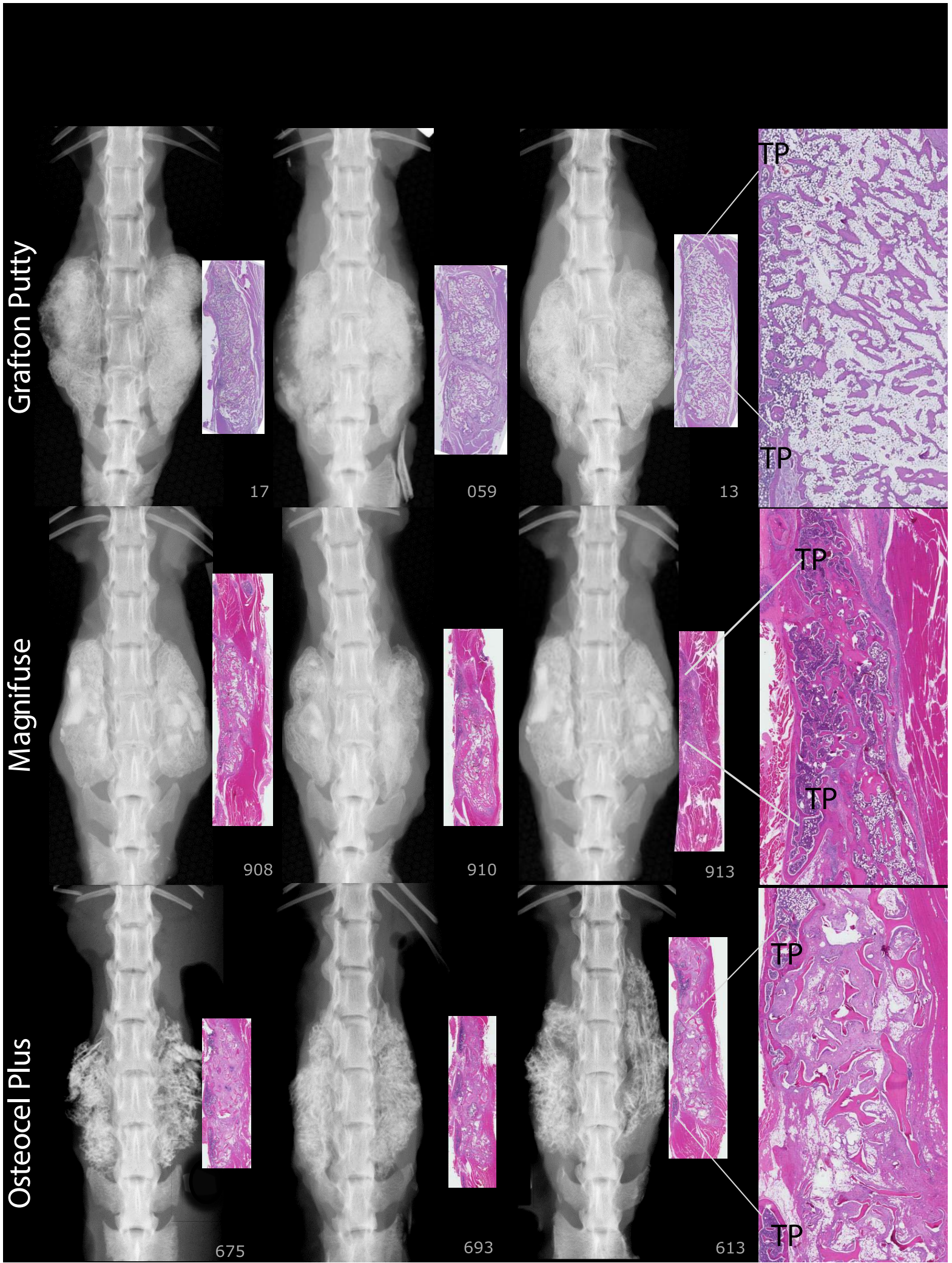

Figure 7. Grafton Putty: Histology shows $77 \%$ new bone, typically with an outer rim of lamellar bone with regular trabeculae, oriented relatively uniformly throughout. Fibrosis is present near clumps of RG. Number 059R: Mildly robust trabeculae are interrupted by a central fibrous tract bisecting the right implant site; histologically not fused on the right but fused on the left. This "nonunion" restricted motion sufficiently that, coupled with the left sided fusion, this rat was evaluated as fused by manual palpation. Magnifuse: There was a rim of lamellar bone surrounding margins of the areas of interest, $65 \%$ new bone with broad, variably shaped trabeculae. Numbers 908 and 910: A thin track of braided material defined the border sites. Number 913: Residual implant material midsection. Osteocel Plus, Number \#613: Shows spaced spicules of residual implant material surrounded by moderate amounts of fibrosis. Scattered multinucleated, giant cells and lymphocytes evenly spaced between TPs. There are no trabeculae of viable lamellar bone bridging TPs. Numerous trabeculae of acellular bone present. Number 675: Small regions of viable trabeculae sprouting out of the original TPs partially encasing spicules of residual implant material, most are nonviable bone surrounded by fibrosis. 


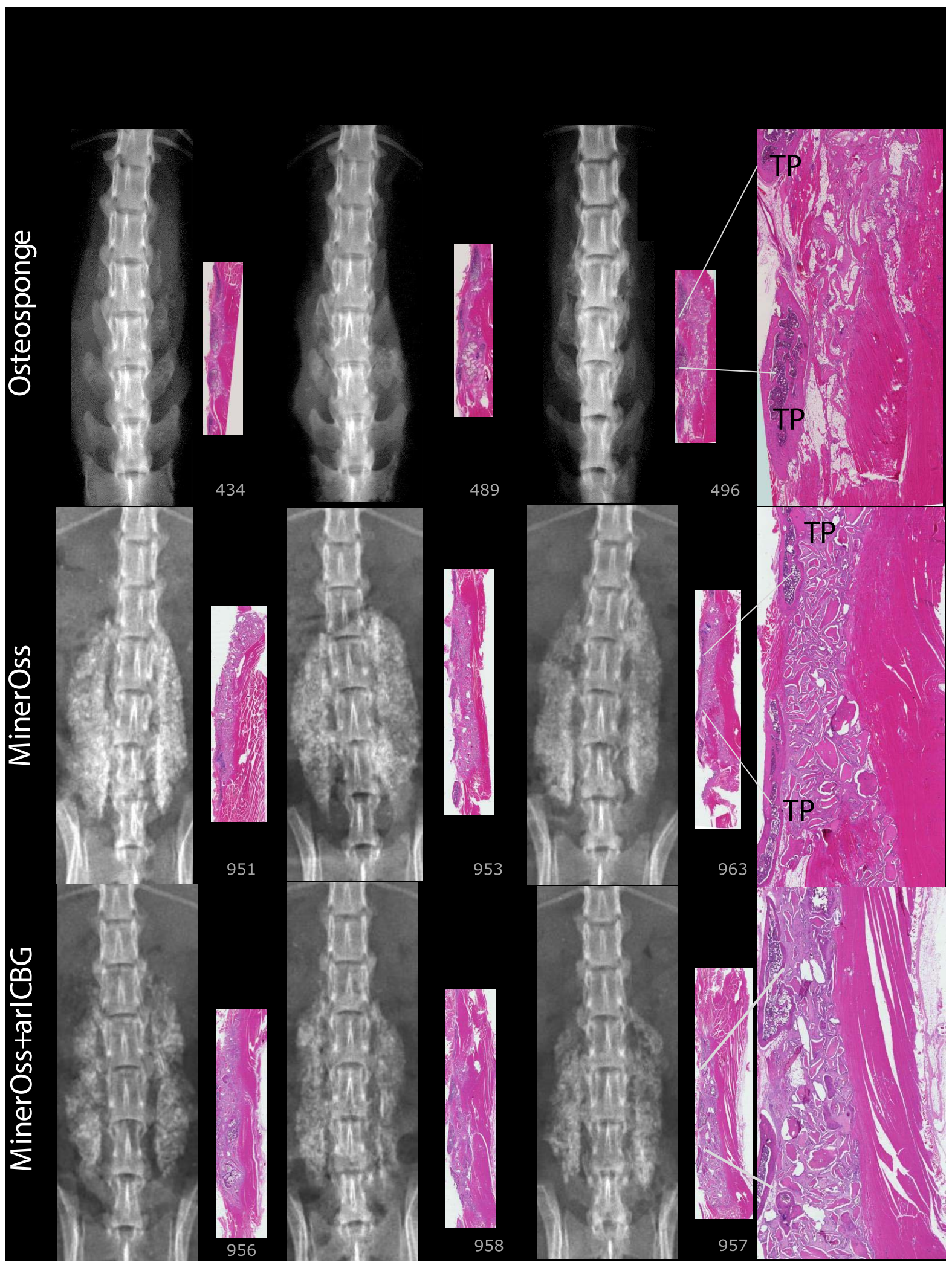

Figure 8. OsteoSponge: There is a subjective compression of the graft material into a small area. Lamellar compact bone matrix was present, yet no woven bone. There is little to no union with TPs. MinerOss, Number 951: Histologically, there is some ongoing endochondral bone formation; however, the majority of the implant site is composed of residual implant and surrounding soft tissue associated with macrophages and giant cells. Number 963 demonstrates significant residual implant with fibrous tissue, macrophages, and giant cells. MinerOss + arlCBG: The addition of arlCBG increased histologic new bone formation from $23 \%$ to $45 \%$ overall; however, this did not result in fusion. Number 956: Islands of bone formation are seen within residual implanted material. Number 958: Lamellar bone formation and endochondral bone formation are ongoing. 


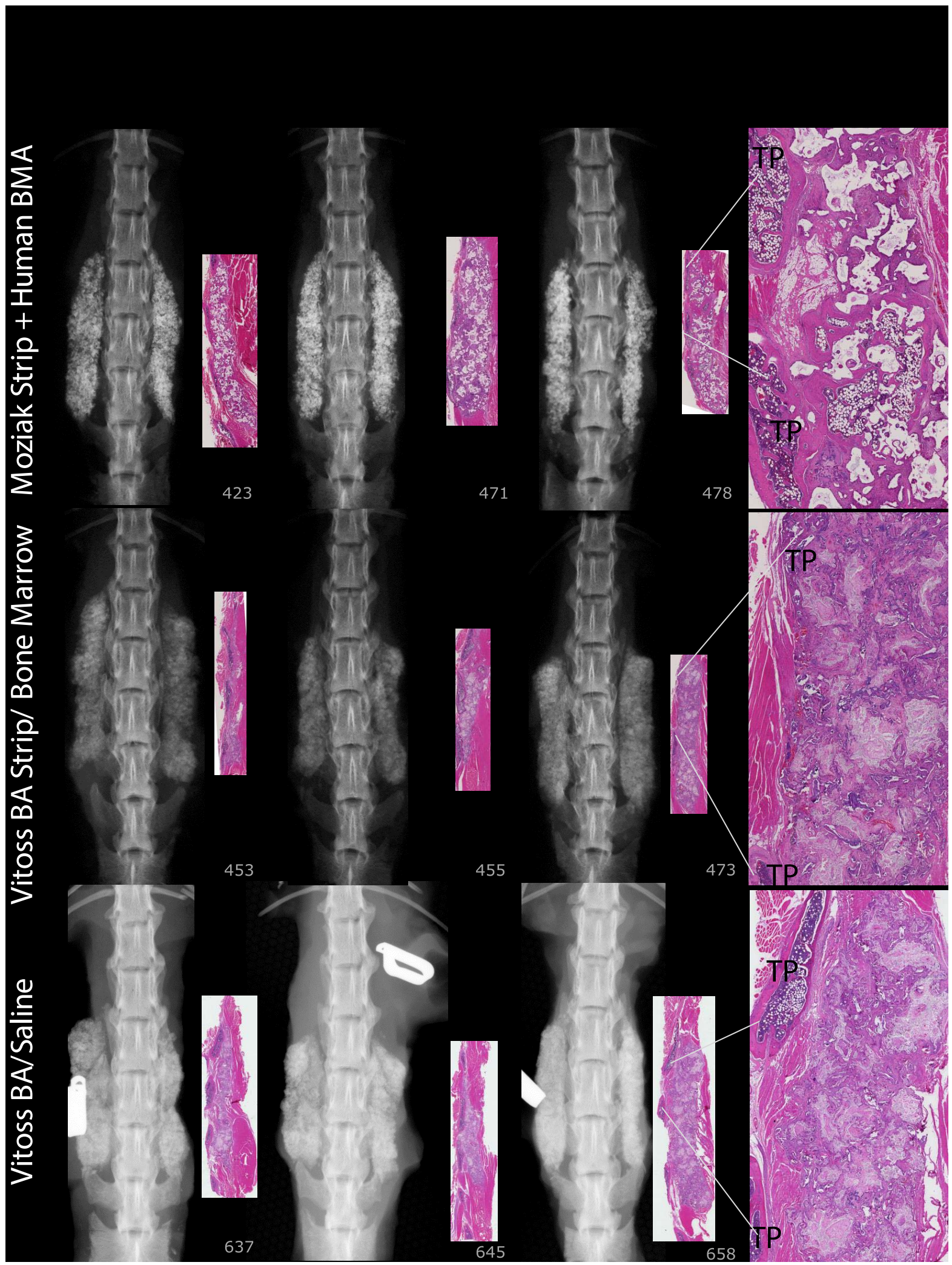

Figure 9. Mozaik Strip + hBMA: The predominant feature is residual implant material with a cellular response composed of macrophages and giant cells. Vitoss BA Strip + hBMA: The predominant cellular response was composed of macrophages and giant cells for all specimens. The addition of hBMA increased histologic new bone formation from $12 \%$ to $34 \%$, and reduced fibrous tissue from $63 \%$ to $11 \%$; however, there was no fusion. Vitoss BA Strip + Saline: Sections reveal finely stippled amphiphilic residual material surrounded by mineralization, scattered multinucleated giant cells, and macrophages. Lamellar bone present was limited to the region close to the decorticated TPs. Number 658 demonstrates $75 \%$ fibrous tissue. 


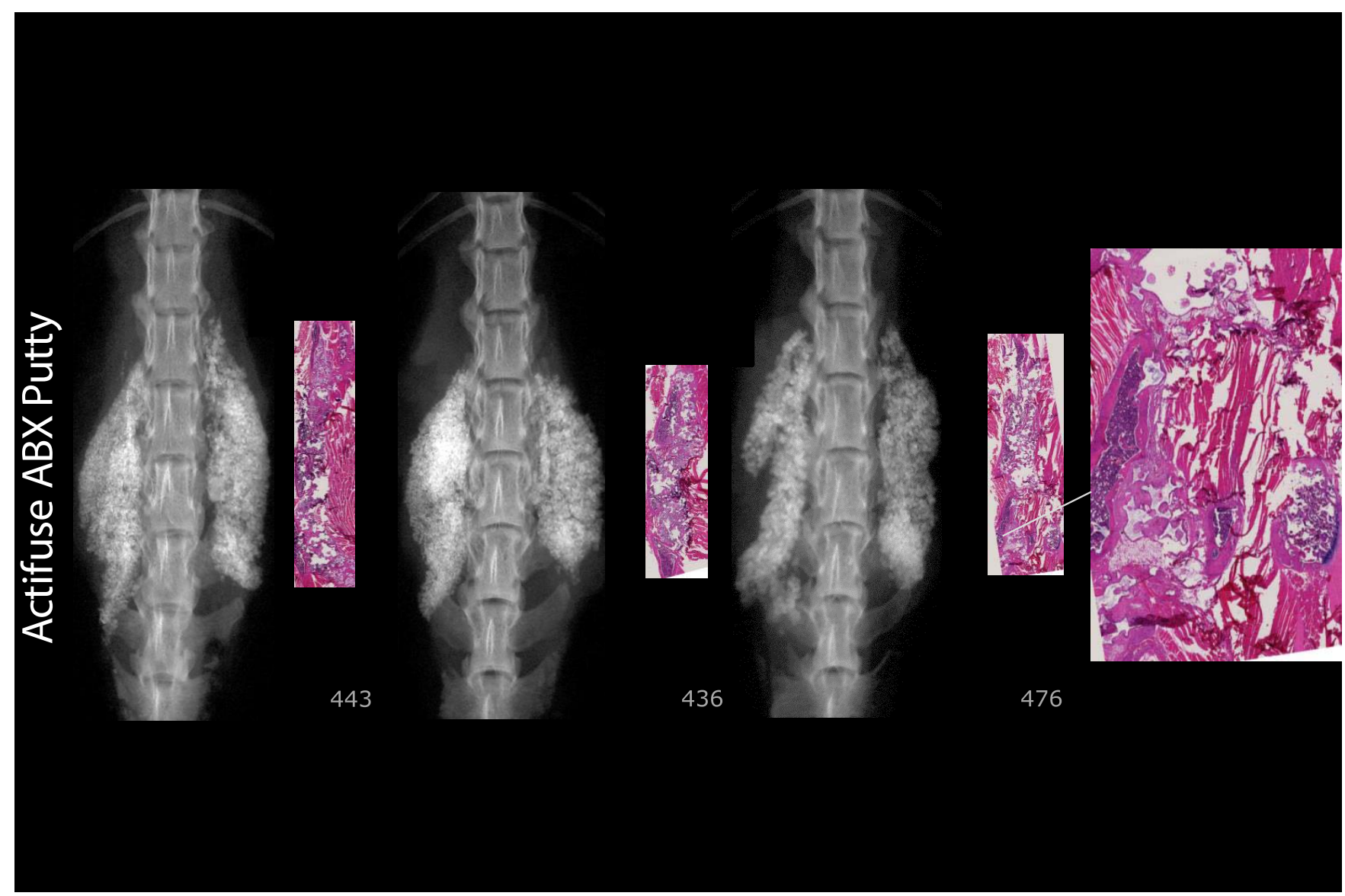

Figure 10. Actifuse ABX Putty number 476 is typical, with residual implant material and minimal lamellar bone/cartilage matrix. No bony fusion connecting TPs.

this material, potentially questioning clinical efficacy to justify the added cost.

OsteoSponge histology was unique: the implant compressed in total volume significantly with implantation. This biased new bone formation evaluation; analysis stated $60 \%$, however, this is misleading as volume of new bone is small due to the graft compression. The small volume of bone was unable to support fusion across TPs. This demonstrates the clinical importance of structural support to material selection.

\section{Demineralized Bone Matrix-based}

Prior studies of allograft-DBMs in single-level fusion procedure in athymic rats have demonstrated fusion rates between $20 \%$ and $80 \%{ }^{7,50}$ When comparing only to materials tested within our study and at similar doses, 2 versions (Grafton Putty and Grafton Flex) have demonstrated fusion rates of $65 \%$ to $100 \%$ and 1 (DBX) a rate of $50 \% .{ }^{11,51}$ One study demonstrated a fusion rate of $39 \%$ for 1 putty (Grafton Putty), but the dose used was $0.4 \mathrm{~cm}^{3} /$ level instead of the $0.6 \mathrm{~cm}^{3} /$ level used here and in other referenced studies. ${ }^{63}$ Accell Evo3 demonstrated greater fusion on manual palpitation than via histologic analysis in this study, possibly indicating an ongoing process of ossification revealed in the histologic sections. Similarly high fusion results for 2 DBMs (Accell Evo3 and Grafton Putty) were recently reported by Brecevich et al. ${ }^{77}$ Here, these allograft-DBMs resulted in $\mathrm{F}_{\mathrm{MP}}>88 \%$.

Results demonstrate these graft materials perform in a 2-level fusion despite the increase in strain. Three allograft-DBMs failed, suggesting low material efficacy, although lot variability exists.

\section{Controls}

\section{$\operatorname{arlCBG}$}

In a study by Lee et al, ${ }^{50}$ rat tail autograft failed to promote PLF in an athymic rat model. Despite selection of arICBG over rat tail autograft, minimal $\mathrm{F}_{\mathrm{MP}}$ was observed, suggesting an opportunity to refine arICBG application, particularly as histology demonstrated early bone formation that had not yet progressed to bridging bone. 


\section{rhBMP-2}

It was previously demonstrated that rhBMP-2 concentrations of 0.032 to $0.160 \mathrm{mg} / \mathrm{mL}$ resulted in $100 \%$ manually fused single-level L4-5 PLF in mature female Lewis rats; at $0.006 \mathrm{mg} / \mathrm{mL}$, fusion rate was $33 \%$ to $50 \% .{ }^{17}$ The current study found a concentration of $0.006 \mathrm{mg} / \mathrm{mL}$ achieved $100 \%$ manually fused $\left(F_{M P}\right)$ in this 2-level model.

\section{Current Experience and Limitations}

The common feature in materials with high fusion rates appears to be the availability of concentrated osteoinductive factors. DBMs induced fusion positively correlated with the concentration of BMPs in each DBM sample using a similar model. ${ }^{7,17,50,63}$

The ability of a material to successfully fuse in the PLF was positively correlated with osteoinductivity via OIS $(r=0.72)$. It may be inferred that successful bone healing is primarily assisted by the osteoinductive component of a material assuming a favorable biocompatible scaffold is in place.

We selected male rats to minimize variance secondary to hormonal fluctuations. However, this limits comparison with historic experiments using female rats. We also note that we used an 8-week time point, whereas some referenced studies used 6 weeks.

\section{Future Research}

Some materials were downsized to fit the animal; however, the "ideal" particle size for rats is unknown. Fusion rates show dependency on particle size (unpublished pilot studies ${ }^{78}$ ). Histology showed residual acellular graft, likely oversized, in some nonfusing materials. Autograft success in larger rabbits supports this concept. ${ }^{65}$

The volume of bone graft material, area and depth of TP decortication, extent of surgical dissection and time point to sacrifice have not been standardized. ${ }^{17,50,63,65,79,80}$ Overdissection dilutes bioactive molecule effect; rhBMP-2 in a muscle pouch only creates bone when adhered to its collagen sponge (or other carrier/scaffold) and not freely diluted away. ${ }^{81}$ Other experimental options include interbody fusion.

\section{CONCLUSION}

In summary, this is a comprehensive attempt testing a multitude of commercially available bone graft substitutes across several classes in a side-byside comparison, in an animal model where fusion is a challenge to achieve and relies on effective grafting products. We demonstrated BMPs and DBMs fused at a higher rate compared with the alternative graft options: cellular allografts (Osteocel) and synthetics (Vitoss, Mosaic, Actifuse). These results were generally consistent across the OIS study (objective 1) and the PLF study (objective 2), as evidenced by statistical measurement of consistency (objective 3 ). Two materials were exceptions, 1 DBM-based product (Progenix Plus) and 1 plain allograft (OsteoSponge). These animal model data provide an indication of clinical efficacy.

Currently, surgeons are challenged to provide the best and most efficacious grafting options for our patients at reasonable costs. Graft adjuncts are often combined in clinical use, and may be mixed with autograft (local bone) to optimize bone healing and fusion. Future testing of combinations such as these may reveal synergies not apparent on the single material experiment presented here. However, the results of this study help to address the paucity of clinical data ${ }^{82}$ and preclinical data to support decisions on selection of individual grafting materials to optimize bone healing in spinal fusion.

\section{ACKNOWLEDGMENTS}

Direct costs were primarily funded by Medtronic. Support for this study was provided by Cedars-Sinai Medical Center, the Spine Research Foundation Los Angeles, and the Foundation for Spinal Restoration.

\section{REFERENCES}

1. Kurien T, Pearson RG, Scammell BE. Bone graft substitutes currently available in orthopaedic practice: the evidence for their use. Bone Jt J. 2013;95-B(5):583-597.

2. Kaiser MG, Groff MW, Watters WC, et al. Guideline update for the performance of fusion procedures for degenerative disease of the lumbar spine. Part 16: bone graft extenders and substitutes as an adjunct for lumbar fusion. $J$ Neurosurg Spine. 2014;21(1):106-132.

3. Bhatt RA, Rozental TD. Bone graft substitutes. Hand Clin. 2012;28(4):457-468.

4. Campana V, Milano G, Pagano E, et al. Bone substitutes in orthopaedic surgery: from basic science to clinical practice. $J$ Mater Sci Mater Med. 2014;25(10):2445-2461.

5. Faour O, Dimitriou R, Cousins CA, Giannoudis PV. The use of bone graft substitutes in large cancellous voids: any specific needs? Injury. 2011;42(suppl 2):S87-S90.

6. Greenwald AS, Boden SD, Goldberg VM, Khan Y, 
Laurencin CT, Rosier RN. Bone-graft substitutes: facts, fictions, and applications. J Bone Jt Surg. 2001;83(2 suppl 2):S98-S103.

7. Bae H, Zhao L, Zhu D, Kanim LE, Wang JC, Delamarter RB. Variability across ten production lots of a single demineralized bone matrix product. J Bone Jt Surg. 2010;92(2):427-435.

8. Boden SD. Bone repair and enhancement clinical trial design. Spine applications. Clin Orthop. 1998;(355 suppl):S336S346.

9. Glassman SD, Carreon L, Djurasovic M, et al. Posterolateral lumbar spine fusion with INFUSE bone graft. Spine $J$. 2007;7(1):44-49.

10. Bae H, Bhamb N, Kanim L, Field J. Bone grafts, bone morphogenetic proteins, and bone substitutes. In: Boyer MI, ed. AAOS Comprehensive Orthopaedic Review. 2nd edition. Rosemont, IL: American Academy of Orthopaedic Surgeons; 2014:73-80.

11. Peterson B, Whang PG, Iglesias R, Wang JC, Lieberman JR. Osteoinductivity of commercially available demineralized bone matrix. J Bone Jt Surg. 2004;86(10):2243-2250.

12. Loeffler BJ. Prospective observational study of donorsite morbidity following anterior iliac crest bone-grafting in orthopaedic trauma reconstruction patients. J Bone Jt Surg Am. 2012;94(18):1649.

13. Myeroff C. Autogenous bone graft: donor sites and techniques. J Bone Jt Surg Am. 2011;93(23):2227.

14. Summers BN, Eisenstein SM. Donor site pain from the ilium. A complication of lumbar spine fusion. J Bone Joint Surg Br. 1989;71-B(4):677-680.

15. Bhamb B, Brown D, Hariharan J, Anderson J, Balousek S, Fleming MF. Survey of select practice behaviors by primary care physicians on the use of opioids for chronic pain. Curr Med Res Opin. 2006;22(9):1859-1865.

16. American Academy of Orthopaedic Surgeons. Bonegraft substitutes: facts, fictions \& applications. 2003. http:// www.aaos.org/research/committee/biologic/BI_SE_2003-1.pdf. Accessed December 8, 2014.

17. Bae HW, Zhao L, Kanim LEA, Wong P, Marshall D, Delamarter RB. Bone marrow enhances the performance of rhBMP-2 in spinal fusion: a rodent model. J Bone Jt Surg. 2013;95(4):338-347.

18. Oryan A, Alidadi S, Moshiri A, Maffulli N. Bone regenerative medicine: classic options, novel strategies, and future directions. J Orthop Surg. 2014;9(1):18.

19. Jones JR. Review of bioactive glass: from Hench to hybrids. Acta Biomater. 2013;9(1):4457-4486.

20. Philippart A, Boccaccini AR, Fleck C, Schubert DW, Roether JA. Toughening and functionalization of bioactive ceramic and glass bone scaffolds by biopolymer coatings and infiltration: a review of the last 5 years. Expert Rev Med Devices. 2015;12(1):93-111.

21. Hench LL, Polak JM. Third-generation biomedical materials. Science. 2002;295(5557):1014-1017.

22. Hench L, Splinter R, Allen W, Greenlee T. Mechanisms of interfacial bonding between ceramics and bone. $J$ Biomed Mater Res Symp. 1971;117-141.

23. García-Gareta E, Coathup MJ, Blunn GW. Osteoinduction of bone grafting materials for bone repair and regeneration. Bone. 2015;81:112-221.
24. Ehrler DM, Vaccaro AR. The use of allograft bone in lumbar spine surgery. Clin Orthop. 2000;(371):38-45.

25. Bae HW, Zhao L, Kanim LEA, Wong P, Delamarter $\mathrm{RB}$, Dawson EG. Intervariability and intravariability of bone morphogenetic proteins in commercially available demineralized bone matrix products. Spine (Phila Pa 1976). 2006;31(12):1299-306; discussion 1307-1308.

26. US Food and Drug Administration. Center for devices and radiological health: overview of medical devices and their regulatory pathways. 2014. http://www.fda.gov/AboutFDA/ CentersOffices/OfficeofMedicalProductsandTobacco/CDRH/ CDRHTransparency/ucm203018.htm. Accessed December 10, 2014.

27. Feldman MD, Petersen AJ, Karliner LS, Tice JA. Who is responsible for evaluating the safety and effectiveness of medical devices? The role of independent technology assessment. J Gen Intern Med. 2008;23(suppl 1):57-63.

28. Kurd M, Cohick S, Park A, Ahmadinia K, Lee J, An H. Fusion in degenerative spondylolisthesis: comparison of osteoconductive and osteoinductive bone graft substitutes. Eur Spine J. 201524(5):1066-1073.

29. Ma J, Both SK, Yang F, et al. Concise review: cell-based strategies in bone tissue engineering and regenerative medicine. Stem Cells Transl Med. 2014;3(1):98-107.

30. Tran CT, Gargiulo C, Thao HD, Tuan HM, Filgueira L, Michael Strong D. Culture and differentiation of osteoblasts on coral scaffold from human bone marrow mesenchymal stem cells. Cell Tissue Bank. 2011;12(4):247-261.

31. Neman J, Duenas V, Kowolik CM, Hambrecht AC, Chen MY, Jandial R. Lineage mapping and characterization of the native progenitor population in cellular allograft. Spine $J$. 2013;13(2):162-174.

32. Ammerman JM, Libricz J, Ammerman MD. The role of Osteocel Plus as a fusion substrate in minimally invasive instrumented transforaminal lumbar interbody fusion. Clin Neurol Neurosurg. 2013;115(7):991-994.

33. Hollawell SM. Allograft cellular bone matrix as an alternative to autograft in hindfoot and ankle fusion procedures. J Foot Ankle Surg. 2012;51(2):222-225.

34. Tohmeh AG, Watson B, Tohmeh M, Zielinski XJ. Allograft cellular bone matrix in extreme lateral interbody fusion: preliminary radiographic and clinical outcomes. Sci World J. 2012;2012:1-8.

35. Urist MR. Bone: formation by autoinduction. Science. 1965;150(3698):893-899.

36. Urist MR, Strates BS. Bone morphogenetic protein. $J$ Dent Res. 1971;50(6):1392-1406.

37. Ronga M, Fagetti A, Canton G, Paiusco E, Surace MF, Cherubino P. Clinical applications of growth factors in bone injuries: Experience with BMPs. Injury. 2013;44(suppl 1):S34S39.

38. Mroz TE, Wang JC, Hashimoto R, Norvell DC. Complications related to osteobiologics use in spine surgery: a systematic review. Spine (Phila Pa 1976). 2010;35(9 suppl):S86S104.

39. Kanakaris NK, Lasanianos N, Calori GM, et al. Application of bone morphogenetic proteins to femoral nonunions: a 4-year multicentre experience. Injury. 2009;40(suppl 3):S54-S61.

40. Desai PP, Bell AJ, Suk M. Treatment of recalcitrant, 
multiply operated tibial nonunions with the RIA graft and rhBMP2 using intramedullary nails. Injury. 2010;41:S69-S71.

41. Fu R, Selph S, McDonagh M, et al. Effectiveness and harms of recombinant human bone morphogenetic protein-2 in spine fusion: a systematic review and meta-analysis. Ann Intern Med. 2013;158(12):890-902.

42. Simmonds MC, Brown JVE, Heirs MK, et al. Safety and effectiveness of recombinant human bone morphogenetic protein-2 for spinal fusion: a meta-analysis of individualparticipant data. Ann Intern Med. 2013;158(12):877-889.

43. Carragee EJ, Baker RM, Benzel EC, et al. A biologic without guidelines: the YODA project and the future of bone morphogenetic protein-2 research. Spine J. 2012;12(10):877880.

44. Hoffmann MF, Jones CB, Sietsema DL. Recombinant human bone morphogenetic protein-2 (rhBMP-2) in posterolateral lumbar spine fusion: complications in the elderly. $J$ Orthop Surg Res. 2013;8:1.

45. Hurlbert RJ, Alexander D, Bailey S, et al. rhBMP-2 for posterolateral instrumented lumbar fusion: a multicenter prospective randomized controlled trial. Spine (Phila $\mathrm{Pa}$ 1976). 2013;38(25):2139-2148.

46. Cahill KS, Chi JH, Groff MW, McGuire K, Afendulis $\mathrm{CC}$, Claus EB. Outcomes for single-level lumbar fusion: the role of bone morphogenetic protein. Spine (Phila Pa 1976). 2011;36(26):2354-2362.

47. Medtronic. Infuse bone graft: information for healthcare providers. 2014. http://www.infusebonegraft.com/healthcareproviders/about-infuse-bonegraft/index.htm. Accessed October $15,2018$.

48. Dawson E, Bae HW, Burkus JK, Stambough JL, Glassman SD. Recombinant human bone morphogenetic protein-2 on an absorbable collagen sponge with an osteoconductive bulking agent in posterolateral arthrodesis with instrumentation a prospective randomized trial. J Bone Jt Surg. 2009;91(7):1604-1613.

49. Jones AL, Bucholz RW, Bosse MJ, et al. Recombinant human BMP-2 and allograft compared with autogenous bone graft for reconstruction of diaphyseal tibial fractures with cortical defects: a randomized, controlled trial. J Bone Jt Surg. 2006;88(7):1431-1441.

50. Lee Y-P, Jo M, Luna M, Chien B, Lieberman JR, Wang JC. The efficacy of different commercially available demineralized bone matrix substances in an athymic rat model. $J$ Spinal Disord Tech. 2005;18(5):439-444.

51. Wang JC, Alanay A, Mark D, et al. A comparison of commercially available demineralized bone matrix for spinal fusion. Eur Spine J. 2007;16(8):1233-1240.

52. Kirk JF, Ritter G, Waters C, Narisawa S, Millán JL, Talton JD. Osteoconductivity and osteoinductivity of NanoFUSE DBM. Cell Tissue Bank. 2013;14(1):33-44.

53. Zhang M, Powers RM, Wolfinbarger L. A quantitative assessment of osteoinductivity of human demineralized bone matrix. J Periodontol. 1997;68(11):1076-1084.

54. Edwards JT, Diegmann MH, Scarborough NL. Osteoinduction of human demineralized bone: characterization in a rat model. Clin Orthop. 1998;(357):219-228.

55. Traianedes K, Russell JL, Edwards JT, Stubbs HA, Shanahan IR, Knaack D. Donor age and gender effects on osteoinductivity of demineralized bone matrix. J Biomed Mater Res B Appl Biomater. 2004;70(1):21-29.
56. Diwan AD, Khan SN, Cammisa FP, Sandhu HS, Lane JM. Nitric oxide modulates recombinant human bone morphogenetic protein-2-induced corticocancellous autograft incorporation: a study in rat intertransverse fusion. Eur Spine J. 2010;19(6):931-939.

57. Robinson ST, Svet MT, Kanim LA, Metzger MF. Fourpoint bending as a method for quantitatively evaluating spinal arthrodesis in a rat model. Comp Med. 2015;65(1):46-50.

58. Cottrell JM, van der Meulen MCH, Lane JM, Myers ER. Assessing the stiffness of spinal fusion in animal models. HSS J. 2006;2(1):12-18.

59. Patel VV, Zhao L, Wong $\mathrm{P}$, et al. An in vitro and in vivo analysis of fibrin glue use to control bone morphogenetic protein diffusion and bone morphogenetic protein-stimulated bone growth. Spine J. 2006;6(4):397-403.

60. Hsu WK. Stem cells from human fat as cellular delivery vehicles in an athymic rat posterolateral spine fusion model. $J$ Bone Jt Surg Am. 2008;90(5):1043.

61. Lee JH, Baek H-R, Lee KM, et al. The effect of poloxamer 407-based hydrogel on the osteoinductivity of demineralized bone matrix. Clin Orthop Surg. 2014;6(4):455.

62. Kleinschmidt K, Wagner-Ecker M, Bartek B, Holschbach J, Richter W. Superior angiogenic potential of GDF-5 and GDF-5V453/V456 compared with BMP-2 in a rabbit long-bone defect model. J Bone Jt Surg. 2014;96(20):1699-1707.

63. Bomback DA, Grauer JN, Lugo RB, Troiano NM, Patel TC, Friedlaender GE. Comparison of posterolateral lumbar fusion rates of grafton putty and op-1 putty in an athymic rat model. Spine (Phila Pa 1976). 2004;29(15):16121617.

64. Li W, Lee M, Whang J, et al. Delivery of lyophilized nell-1 in a rat spinal fusion model. Tissue Eng Part $A$. 2010;16(9):2861-2870.

65. Kiely PD, Brecevich AT, Taher F, Nguyen JT, Cammisa FP, Abjornson C. Evaluation of a new formulation of demineralized bone matrix putty in a rabbit posterolateral spinal fusion model. Spine J. 2014;14(9):2155-2163.

66. Muschler GF, Negami S, Hyodo A, Gaisser D, Easley K, Kambic H. Evaluation of collagen ceramic composite graft materials in a spinal fusion model. Clin Orthop. 1996;(328):250 260.

67. Miller CP, Jegede K, Essig D, et al. The efficacies of 2 ceramic bone graft extenders for promoting spinal fusion in a rabbit bone paucity model. Spine (Phila Pa 1976). 2012;37(8):642-647.

68. Walsh WR, Vizesi F, Cornwall GB, Bell D, Oliver R, Yu Y. Posterolateral spinal fusion in a rabbit model using a collagen-mineral composite bone graft substitute. Eur Spine J. 2009;18(11):1610-1620.

69. Hing KA, Wilson LF, Buckland T. Comparative performance of three ceramic bone graft substitutes. Spine J. 2007;7(4):475-490.

70. Odri G-A, Revert R, Deschamps C, et al. Effect of adding bone marrow to ceramic graft materials with different interconnectivities in lumbar arthrodesis: quantification of bone formation. J Orthop Sci. 2013;18(2):321-330.

71. Lee JH, Ryu H-S, Seo J-H, Lee D-Y, Chang B-S, Lee C$\mathrm{K}$. Negative effect of rapidly resorbing properties of bioactive glass-ceramics as bone graft substitute in a rabbit lumbar fusion model. Clin Orthop Surg. 2014;6(1):87.

72. Gupta A, Chauhan V, Chauhan N, Sharma S, 
Maheshwari R, Agarwal A. Experimental posterolateral spinal fusion with beta tricalcium phosphate ceramic and bone marrow aspirate composite graft. Indian $J$ Orthop. 2010;44(4):402-408.

73. Chen W, Liu J, Manuchehrabadi N, Weir MD, Zhu Z, $\mathrm{Xu}$ HHK. Umbilical cord and bone marrow mesenchymal stem cell seeding on macroporous calcium phosphate for bone regeneration in rat cranial defects. Biomaterials. 2013;34(38):9917-9925.

74. Satish L, Palmer B, Liu F, et al. Developing an animal model of Dupuytren's disease by orthotopic transplantation of human fibroblasts into athymic rat. BMC Musculoskelet Disord. 2015;16:138.

75. Tamaki T, Uchiyama Y, Hirata M, et al. Therapeutic isolation and expansion of human skeletal muscle-derived stem cells for the use of muscle-nerve-blood vessel reconstitution. Front Physiol. 2015;6:165.

76. Hayashi T, Lord EL, Suzuki A, et al. A comparison of commercially available demineralized bone matrices with and without human mesenchymal stem cells in a rodent spinal fusion model. J Neurosurg Spine. 2016;25(1):133-137.

77. Brecevich AT, Kiely PD, Yoon BV, Nguyen JT, Cammisa FP, Abjornson C. Efficacy comparison of Accell Evo3 and Grafton demineralized bone matrix putties against autologous bone in a rat posterolateral spine fusion model. Spine J. 2017;17(6):855-862.

78. Neto AS, Ferreira JMF. Synthetic and marine-derived porous scaffolds for bone tissue engineering. Mater Basel Switz. 2018;11(9):e1702.

79. Scott TP, Phan KH, Tian H, et al. Comparison of a novel oxysterol molecule and rhBMP2 fusion rates in a rabbit posterolateral lumbar spine model. Spine J. 2015;15(4):733-742.

80. Minamide A, Kawakami M, Hashizume H, Sakata R, Tamaki T. Evaluation of carriers of bone morphogenetic protein for spinal fusion. Spine (Phila Pa 1976). 2001;26(8):933-939.

81. Hsu H-P, Zanella JM, Peckham SM, Spector M. Comparing ectopic bone growth induced by rhBMP-2 on an absorbable collagen sponge in rat and rabbit models. $J$ Orthop Res. 2006;24(8):1660-1669.
82. Kadam A, Millhouse PW, Kepler CK, et al. Bone substitutes and expanders in Spine Surgery: A review of their fusion efficacies. Int J Spine Surg. 2016;10:33.

Disclosures and COI: Dr Bhamb has no conflicts. Dr Bhamb, Ms Kanim, and Dr Bae have had full access to all the data in the study and take responsibility of the integrity of the data and analysis, interpretation of data. Ms Kanim has $<\$ 5000$ stock from a company involved in the manufacture of a device examined in this study. Dr Drapeau and Ms McKay were previous employees, and Mrs Mohan, Mr Vasquez, and Dr Shimko are current employees of a company involved in the manufacture of a device/product examined in this study. Dr. Bae has received research funds from three companies, consulting fee/royalties related to patents from two companies involved in the manufacture of a device/product examined in this study but no conflict related to this study.

Corresponding Author: Hyun Bae, MD, Professor of Surgery, Orthopaedic Surgery, c/o Linda Kanim, MA, Translational and Clinical Research, Spine Center, Cedars-Sinai Medical Center, 444 S San Vicente Blvd, Suite 901, Los Angeles, CA 90048. Phone: (310) 248-7344; Email: linda.kanim@cshs.org.

Published 31 October 2019

This manuscript is generously published free of charge by ISASS, the International Society for the Advancement of Spine Surgery. Copyright (C) 2019 ISASS. To see more or order reprints or permissions, see http://ijssurgery.com. 


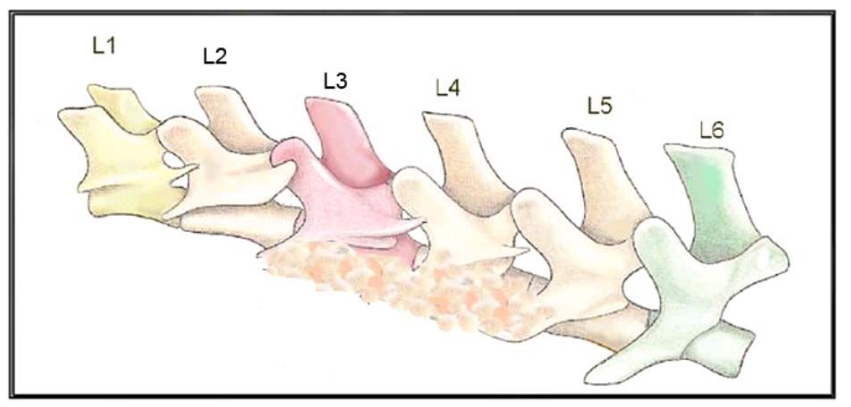

Appendix 1. This represents an athymic rat spine with the typical 6 lumbar vertebral levels ( $L 1-L 6)$, depicting graft material on the TPs of $L 3$ to $L 4$ and $L 4$ to L5.

Appendix 2. PLF study data including $F_{M P}, F_{X R}$, and $F_{\text {HISTO }}$ presented as raw percentage data, grouped by material type.

\begin{tabular}{|c|c|c|c|c|}
\hline \multicolumn{2}{|c|}{ Materials } & \multicolumn{3}{|c|}{ Fusion Rate, \% } \\
\hline Name & Group & Manual Palpation & Radiography & Histology \\
\hline rhBMP-2 (0.1mg/mL) & Control & 100 & 100 & 81 \\
\hline rhBMP-2 $(0.006 \mathrm{mg} / \mathrm{mL})$ & Control & 100 & 100 & 94 \\
\hline $\operatorname{arICBG}$ & Control & 13 & 6 & 0 \\
\hline Sham & Control & 0 & 0 & 0 \\
\hline Accell Evo3 & DBM & 100 & 88 & 50 \\
\hline DBX Mix & DBM & 100 & 100 & 100 \\
\hline DBX Strip & DBM & 100 & 100 & 88 \\
\hline Grafton Crunch & DBM & 94 & 94 & 100 \\
\hline Grafton Flex & DBM & 100 & 100 & 100 \\
\hline Grafton Matrix & DBM & 94 & 88 & 69 \\
\hline Grafton Putty & DBM & 100 & 88 & 94 \\
\hline Magnifuse & DBM & 100 & 100 & 100 \\
\hline Progenix Plus + arICBG & DBM & 0 & 25 & 0 \\
\hline Progenix Plus & DBM & 0 & 0 & 0 \\
\hline OsteoSponge & Allograft & 0 & 0 & 0 \\
\hline MinerOss $+\operatorname{arICBG}$ & Allograft & 0 & 0 & 0 \\
\hline MinerOss & Allograft & 0 & 0 & 0 \\
\hline Osteocel Plus & Cellular Allograft & 0 & 0 & 0 \\
\hline Mozaik Strip + hBMA & Ceramic & 0 & 0 & 0 \\
\hline Actifuse ABX Putty & Activated Ceramic & 0 & 0 & 0 \\
\hline Vitoss BA + hBMA & Activated Ceramic & 0 & 0 & 0 \\
\hline Vitoss $\mathrm{BA}+$ saline & Activated Ceramic & 0 & 0 & 0 \\
\hline
\end{tabular}

